\title{
Symmetry Breaking in Iron(II) Spin-Crossover Molecular Crystals
}

\author{
Norma Ortega-Villar ${ }^{1}$, M. Carmen Muñoz ${ }^{2}$ and José A. Real ${ }^{3, *}$ \\ 1 Facultad de Química (UNAM), Edificio B. Av. Universidad 3000, Coyoacán, 04510 México D.F., Mexico; \\ norma.ortega@uv.es \\ 2 Departamento de Física Aplicada, Universitat Politècnica de València, E-46022 Valencia, Spain; \\ mcmunoz@fis.upv.es \\ 3 Instituto de Ciencia Molecular (ICMol), Universidad de Valencia, 46980 Valencia, Paterna, Spain \\ * Correspondence: jose.a.real@uv.es; Tel.: +34-963-544-359
}

Academic Editor: Carlos J. Gómez García

Received: 12 January 2016; Accepted: 24 February 2016; Published: 11 March 2016

\begin{abstract}
This review provides an up to date survey of a singular class of iron(II) spin crossover (SCO) molecular materials that undergo high-spin (HS) $\leftrightarrow$ low-spin (LS) phase transitions accompanied by crystallographic symmetry breaking (CSB). Particular interest has been focused on a variety of complexes that exhibit one-step or stepwise SCO behavior and CSB. Most of them afford excellent examples of well-ordered 1HS-1LS, 2HS-1LS or 1HS-2LS intermediate phases (IP) and represent an important platform to disclose microscopic mechanisms responsible for cooperativity and ordering in such multistable materials.
\end{abstract}

Keywords: iron(II) complexes; spin crossover; symmetry breaking; crystal structure; magnetic behavior; mononuclear complexes; polynuclear complexes; coordination polymers

\section{Introduction}

Spin crossover (SCO) complexes represent an important class of switchable molecular materials [1-4]. In these complexes, the energy gap between the high-spin (HS) and the low-spin (LS) states is of the order of magnitude of the thermal energy. Consequently, they can adopt both spin states and change from one state to the other state in a reversible, detectable and controllable way through temperature or pressure gradients, light irradiation and chemical stimuli. The LS $\leftrightarrow \mathrm{HS}$ switch is accompanied by distinctive changes in magnetic, optical and dielectric properties. The SCO behavior involves an electronic redistribution between the $t_{2 g}$ and $e_{g}$ orbitals, strongly coupled with structural changes, which mainly affect the coordination core of the metal complex. In the solid state, these structural changes are cooperatively transmitted through elastic interactions and, in favorable cases, first-order spin transition occasionally accompanied by hysteretic behavior confers a binary function to the material. The elastic interactions depend somehow on the intermolecular contacts developed between SCO centers (i.e., van der Waals, hydrogen bonding, $\pi-\pi$ interactions, coordination bonds, etc.) and determine the cooperative character of the $\mathrm{SCO}$, namely steepness, hysteresis and steps. Theoretically explained as the result of a competition between antagonistic short-range and long-range elastic interactions [5-9], observation of steps has been considered for many years an intriguing and relatively rare event. However, the exponential growth experienced by the field in the last decade has uncovered an increasing number of stepwise SCO events featuring ordered intermediate phases (IP) well characterized from a structural viewpoint. There are two distinct situations that account for stepwise transitions. One is observed when different SCO sites, characterized by distinct transition temperatures $\left(T_{1 / 2}\right.$ or $\left.T_{\mathrm{c}}\right)$, are present in the solid [10-17]. The other arises from subtle balances between different elastic interactions in the crystal lattice, which spontaneously generate two or more 
distinct SCO sites. This spontaneous change may occur without significant modification of the unit cell, other than the typical structural changes associated with the LS $\leftrightarrow$ HS conversion. However, a growing number of examples, particularly in the area of $\mathrm{Fe}^{\mathrm{II}}$ complexes, has been found to exhibit crystallographic symmetry breaking (CSB). CSB is characterized by a change of space group type and eventually of crystal system in the IP. Although the occurrence of phase transitions with CSB is ubiquitous in Nature, it is still considered a rare event and an important opportunity to learn new fundamental aspects of the SCO behavior. As far as we know, apart from the Fe $\mathrm{II}^{\mathrm{II}}$ complexes here reviewed only one complex exhibiting SCO and CSB has been described in the chemistry of Co ${ }^{\mathrm{II}}$ [18] and $\mathrm{Mn}^{\mathrm{III}}$ [19], while there are five reports concerning $\mathrm{Fe}^{\mathrm{III}}$ complexes [20-24].

CSB has been partially reviewed by Shatruk et al. in a broader context which, includes displacive transitions, phase transitions caused by disorder, polymorphism, and first order transitions without space group changes [25]. The aim of the present contribution is to update and systematically review the Fe $\mathrm{II}^{\mathrm{II}} \mathrm{SCO}$ systems that manifest half-step, one-step, two-step and multi-step SCO transitions accompanied by CSB. The next three sections are organized according to the nature of the systems: monomeric (Section 2), polynuclear (Section 3), or polymeric (Section 4). Section 2 has been divided in two subsections, one dedicated to mononuclear SCO complexes exhibiting stepwise transitions and ordering in the IP, the other, dedicated to complexes that exhibit complete one-step SCO with CSB. Section 2 essentially describes a series of significant dinuclear SCO compounds that feature CSB. Section 3 is organized according to the one-, two- or three-dimensional nature of the coordination polymer that shows SCO and CSB behavior.

\section{Mononuclear Iron(II) Complexes}

\subsection{Stepwise SCO Behavior}

The prototypical mononuclear $\left[\mathrm{Fe}^{\mathrm{II}}(2-\mathrm{pic})_{3}\right] \mathrm{Cl}_{2} \cdot \mathrm{EtOH}$ (pic = picolylamine) was the first two-step SCO complex investigated extensively [26]. Its structure was analyzed at $115 \mathrm{~K}$ [27] and $90 \mathrm{~K}$ in the LS state and at $150 \mathrm{~K}$ and $298 \mathrm{~K}$ in the HS state [28]. Shortly after, Gütlich et al. observed for this compound the occurrence of a two-step behavior characterized by a small plateau (ca. $10 \mathrm{~K}$ wide) centered at about $119 \mathrm{~K}$, which separates two half spin transitions with $T_{\mathrm{c} 1}=114 \mathrm{~K}$ and $T_{\mathrm{c} 2}=124 \mathrm{~K}$ (Figure 1) [29-31]. The existence of the intermediate plateau was rationalized in terms of concurrence of "ferromagnetic-like" long-range and "antiferromagnetic-like" short-range elastic interactions in the crystal [32]. Almost 20 years after the discovery of this two-step SCO behavior, a detailed structural reinvestigation by Bürgi et al. disclosed the nature of the double phase transition and hence of the plateau in $\left.\left[\mathrm{Fe}^{\mathrm{II}}(2-\mathrm{pic})_{3}\right] \mathrm{Cl}_{2} \cdot \mathrm{EtOH}\right]$. In the LS and $\mathrm{HS}$ states the unit cell is monoclinic, space group $P 2_{1} / c$, and contains one crystallographically independent $\mathrm{Fe}^{\mathrm{II}}$ site. In contrast, in the plateau (IP), the unit cell doubles and accommodates two crystallographically independent $\mathrm{Fe}^{\mathrm{II}}$ sites, which corresponds to a 1:1 mixture of LS and HS states (IP = 1HS-1LS). In the IP, layers of HS molecules alternate with layers of LS molecules defining an ordered ... HS-LS. . pattern. These layers lie approximately in the $b c$ plane and stack along the $a$-axis (Figure 1) [33].

A less common pattern in the IP has been described by Létard, Howard and Halcrow et al. for [Fe(bmpzpy $\left.)_{2}\right]\left(\mathrm{BF}_{4}\right)_{2} \cdot x \mathrm{H}_{2} \mathrm{O}(x=0,1 / 3$; bmpzpy $=2,6$-bis\{3-methylpyrazol-1-yl\}pyridine). This system undergoes an incomplete $\mathrm{SCO}$ where only $1 / 2$ of the $\mathrm{Fe}^{\mathrm{II}}$ centers switches to the LS while the other $1 / 2$ remains HS. This so-called half SCO occurs in two cooperative steps centered at $T_{\mathrm{c} 2}=147 \mathrm{~K}$ and $T_{\mathrm{c} 1}=105 \mathrm{~K}$ with $\Delta T_{\mathrm{c} 2}=6 \mathrm{~K}$ and $\Delta T_{\mathrm{c} 1}=18 \mathrm{~K}$ wide hysteresis loops, respectively (Note: half SCO) (Figure 2). This 50\% mixed spin state is observed when usual temperature scan rates $(1-2 \mathrm{~K} / \mathrm{min})$ are employed at low temperatures, due to slow HS $\leftrightarrow$ LS kinetics. However, it relaxes to the fully LS state in $2 \mathrm{~h}$ at $100 \mathrm{~K}$. 

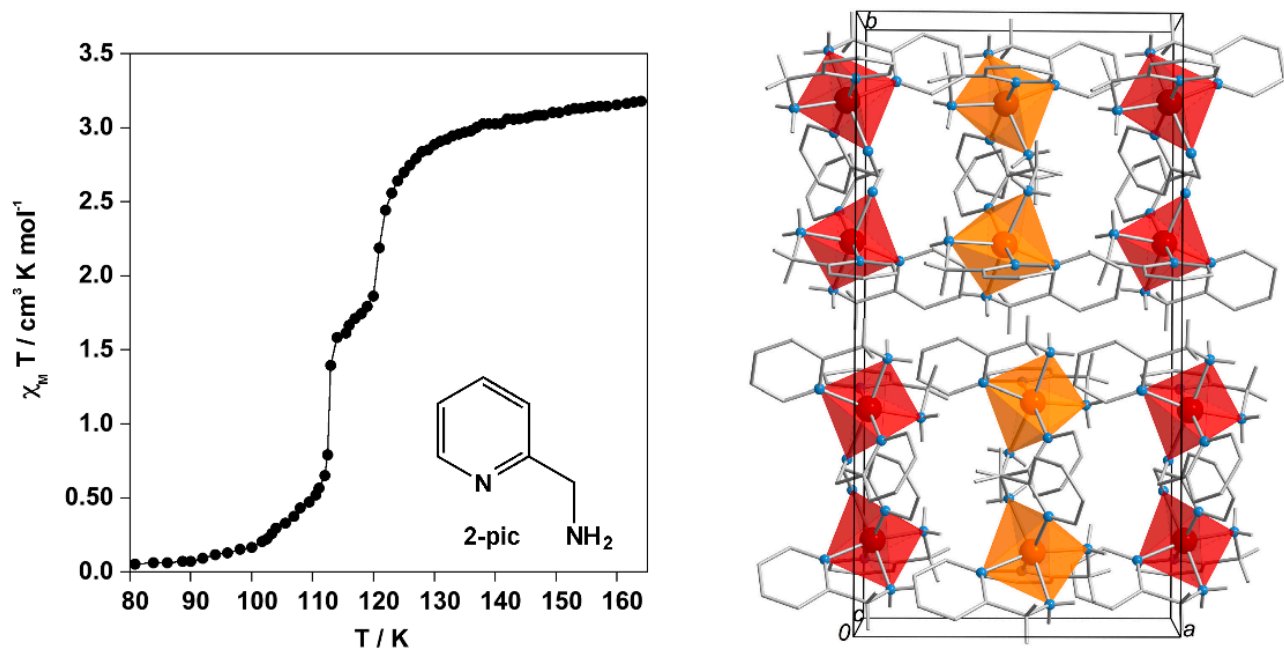

Figure 1. [ $\left.\mathrm{Fe}^{\mathrm{II}}(2-\mathrm{pic})_{3}\right] \mathrm{Cl}_{2}$. EtOH]: Two-step SCO behavior in the $\chi_{\mathrm{M}} \mathrm{T}$ vs. T plot $\left(\chi_{\mathrm{M}}\right.$ is the molar magnetic susceptibility and $\mathrm{T}$ is the temperature) (left). Projection of the unit cell down the $c$-axis in the intermediate phase (IP) (1HS-1LS) showing alternance of the HS (orange) and LS (red) complex cations $\left(\mathrm{Cl}^{-}\right.$anions and EtOH solvent molecules have been omitted) (right).
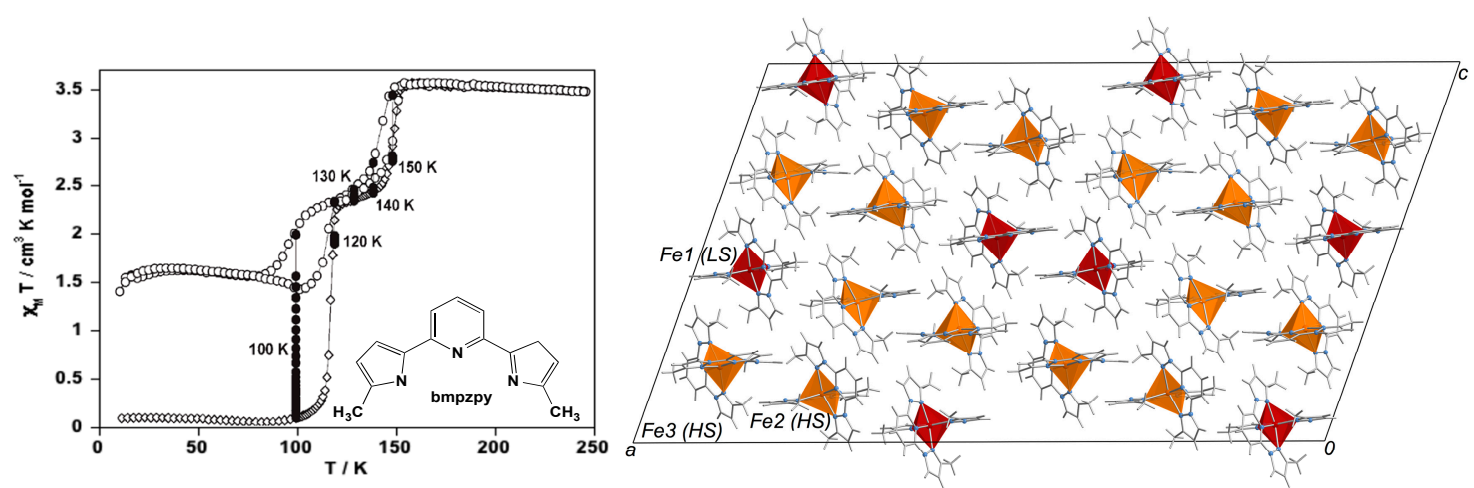

Figure 2. Spin crossover behavior of $\left[\mathrm{Fe}(\mathrm{bmpzpy})_{2}\right]\left(\mathrm{BF}_{4}\right)_{2} \cdot \mathrm{xH}_{2} \mathrm{O}$ (adapted with permission from Reference [34]) (left). Projection of the unit cell down the $b$-axis in the plateau at $130 \mathrm{~K}$ showing the IP = 2HS-1LS (HS, orange; LS, red) (right).

The crystal structures of the anhydrous and the hydrate species $(x=0,1 / 3)$ were investigated at $200 \mathrm{~K}, 130 \mathrm{~K}$ and $90 \mathrm{~K}$. At $200 \mathrm{~K}$, the crystals are monoclinic (space group $\mathrm{C} 2 / \mathrm{c},(\mathrm{Z}=8)$ ) and contain one crystallographically independent $\mathrm{Fe}^{\mathrm{II}}$ site, which is HS. At $130 \mathrm{~K}$, the anhydrous form remains in the same space group type but triples the unit cell $(\mathrm{Z}=24)$ to accommodate three distinct $\mathrm{Fe}^{\mathrm{II}}$ sites, one LS and two HS (IP = 2HS-1LS), a fact consistent with the magnetic behavior. In this ordered state, the unit cell shows two types of chains running along the $c$-axis. One is defined by two $\mathrm{Fe}^{\mathrm{II}}$ sites, $\cdots$ Fe1(LS)-Fe3(HS) $\cdots$, while the other contains a unique Fe2(HS) site. Both kinds of chains alternate along the $a$-axis and superpose along the $b$-axis (Figure 2). At $90 \mathrm{~K}$, after relaxing the mixed state at $100 \mathrm{~K}$, the complex shows one crystallographically independent $\mathrm{Fe}^{\mathrm{II}}$ site, which is LS. At $200 \mathrm{~K}$ and $130 \mathrm{~K}$, the crystal structures of the hydrated and anhydrous compounds are essentially the same since the inclusion of $1 / 3 \mathrm{H}_{2} \mathrm{O}$ molecules seems to not perturb too much the crystal packing. However, in contrast to the anhydrous compound, all the $\mathrm{Fe}^{\mathrm{II}}$ centers of the hydrated derivative remain in the HS state at $130 \mathrm{~K}$. At $90 \mathrm{~K}$, the structure of the hydrated derivative is similar to that of the anhydrous compound at $130 \mathrm{~K}[34]$. 
The same IP = 2HS-1LS has been recently reported by Bao and Tong et al. for the polymorph A of complex [Fe(bpmen)(NCSe) $)_{2}$ (bpmen is the tetradentate ligand $N, N^{\prime}$-dimethyl- $N, N^{\prime}-$ bis $(2-$ pyridylmethyl)-1,2-ethanediamine). This compound undergoes a complete cooperative two-step SCO characterized by a first drop in the thermal dependence of the $\chi_{M} T$ product ( $\chi_{M}$ is the molar magnetic susceptibility and $T$ temperature) from $3.2 \mathrm{~cm}^{3} \cdot \mathrm{K} \cdot \mathrm{mol}^{-1}$ (HS state) to $2.6 \mathrm{~cm}^{3} \cdot \mathrm{K} \cdot \mathrm{mol}^{-1}$ (IP state). This step, characterized by a hysteresis loop $5 \mathrm{~K}$ wide centered at $T_{\mathrm{c} 2}=117.5 \mathrm{~K}$, reflects the conversion of $1 / 3$ of the HS centers to the LS state. The second drop in $\chi_{\mathrm{M}} T$ (between $2.2 \mathrm{~cm}^{3} \cdot \mathrm{K} \cdot \mathrm{mol}^{-1}$ and $0.2 \mathrm{~cm}^{3} \cdot \mathrm{K} \cdot \mathrm{mol}^{-1}$ ), characterized by a hysteresis loop $10 \mathrm{~K}$ wide centered at $T_{\mathrm{c} 1}=101 \mathrm{~K}$, involves the remaining $2 / 3$ of the HS species. The crystals of this polymorph are orthorhombic, its space group being $A b a 2$, and contain one asymmetric unit defined by half a molecule with a two-fold axis passing through the $\mathrm{Fe}^{\mathrm{II}}$ site. The molecules are arranged in layers that stack along the $a$-axis and extend parallel to the plane $b c$. At $100 \mathrm{~K}$ (IP state) the unit cell triples displaying a HS-HS-LS pattern. However, the order in this IP = 2HS-1LS is produced in a different way to that described in the previous example, namely a layer constituted of Fe2(LS) sites is separated by two consecutive identical layers made up of Fe1(HS) sites (Figure 3) [35].
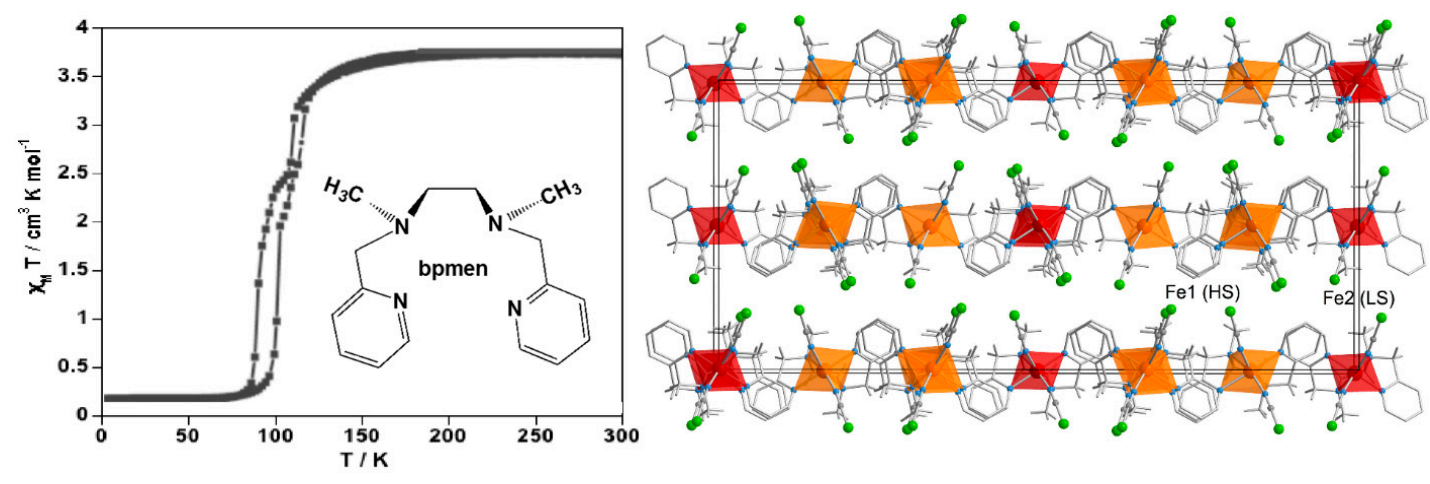

Figure 3. [Fe(bpmen)(NCSe) 2 ]: Spin crossover behavior (adapted with permission from Reference [35]) (left). Projection of the unit cell down the $c$-axis showing the ordering in the IP $=2$ HS-1LS (right). Red and orange octahedrons correspond to LS and HS sites, respectively.

The multicomponent mononuclear complex $\left[\mathrm{Fe}^{\mathrm{II}}(\mathrm{dpp})_{2}\right]\left[\mathrm{Ni}(\mathrm{mnt})_{2}\right]_{2} \cdot \mathrm{MeNO}_{2},(\mathrm{dpp}=2,6$-bis (pyrazol-1-yl)pyridine (see Figure A1) and mnt = maleonitriledithiolate) displays a complicated SCO behavior. Above $180 \mathrm{~K}$, the Fe centers are HS but abruptly change to the LS state below this temperature. In contrast, in the heating mode the population of the $\mathrm{Fe}^{\mathrm{II}} \mathrm{HS}$ species increases showing three steps defining an irregular hysteresis. Although crystallographic evidence of order in the intermediate states could only be partially demonstrated for the first plateau (1HS-2LS), where the unit cell triples to contain three distinct $\mathrm{Fe}^{\mathrm{II}}$ centers, it could be concluded from magnetic susceptibility and Mössbauer data that the steps corresponds to the LS $\stackrel{\text { step } 1}{\leftrightarrow} 1 H S: 2 L S \stackrel{\text { step } 2}{\leftrightarrow} 2 H S: 1 L S \stackrel{\text { step } 3}{\leftrightarrow} H S$ sequence [36].

Despite the nature of the $\mathrm{SCO}$ in $\left.\left[\mathrm{Fe}^{\mathrm{II}}(2-\text { pic })_{3}\right] \mathrm{Cl}_{2} \cdot \mathrm{EtOH}\right]$ has attracted much attention for two decades, the first structurally investigated two-step SCO with CSB was reported by Tuchagues et al. for the complex $\left[\mathrm{Fe}^{\mathrm{II}}\left\{5-\mathrm{NO}_{2}\right.\right.$-sal-N $\left.\left.(1,4,7,10)\right\}\right]$, where 5- $\mathrm{NO}_{2}$-sal-N $(1,4,7,10)$ is a six-coordinating ligand prepared by Schiff base condensation of $5-\mathrm{NO}_{2}$-salicylaldehyde with 1,4,7,10-tetraazadecane [37]. The magnetic data showed the occurrence of two cooperative half spin transitions centered at $T_{\mathrm{c} 2}=176 \mathrm{~K}$ and $T_{\mathrm{c} 1}=142 \mathrm{~K}$ with hysteresis loops $3 \mathrm{~K}$ and $8 \mathrm{~K}$ wide, respectively (Figure 4 ). In the HS state, the crystal is monoclinic, its space group being $P 2 / c$, and is characterized by the presence of one $\mathrm{Fe}^{\mathrm{II}}$ HS site. The high temperature step, HS $\rightarrow$ IP, occurs simultaneously with a change of the crystal to the space group P2. The loss of the inversion center in the IP also involves the generation of two crystallographically independent $\mathrm{Fe}^{\mathrm{II}}$ centers. In the subsequent IP $\rightarrow$ LS step the crystal loses the two-fold symmetry axes and becomes triclinic (space group P1). Contrary to expectations, the average 
metal-to-ligand bond length of the $\left[\mathrm{FeN}_{4} \mathrm{O}_{2}\right]$ coordination center is virtually the same for the $\mathrm{HS}$ and the IP states and only $0.1 \AA$ larger than that observed for the LS state at $103 \mathrm{~K}$. Consequently, no crystallographic evidence of IP with an ordering ... HS-LS ... was afforded for this complex. This problem was reinvestigated by Gütlich et al. but no clear conclusion was achieved [32].

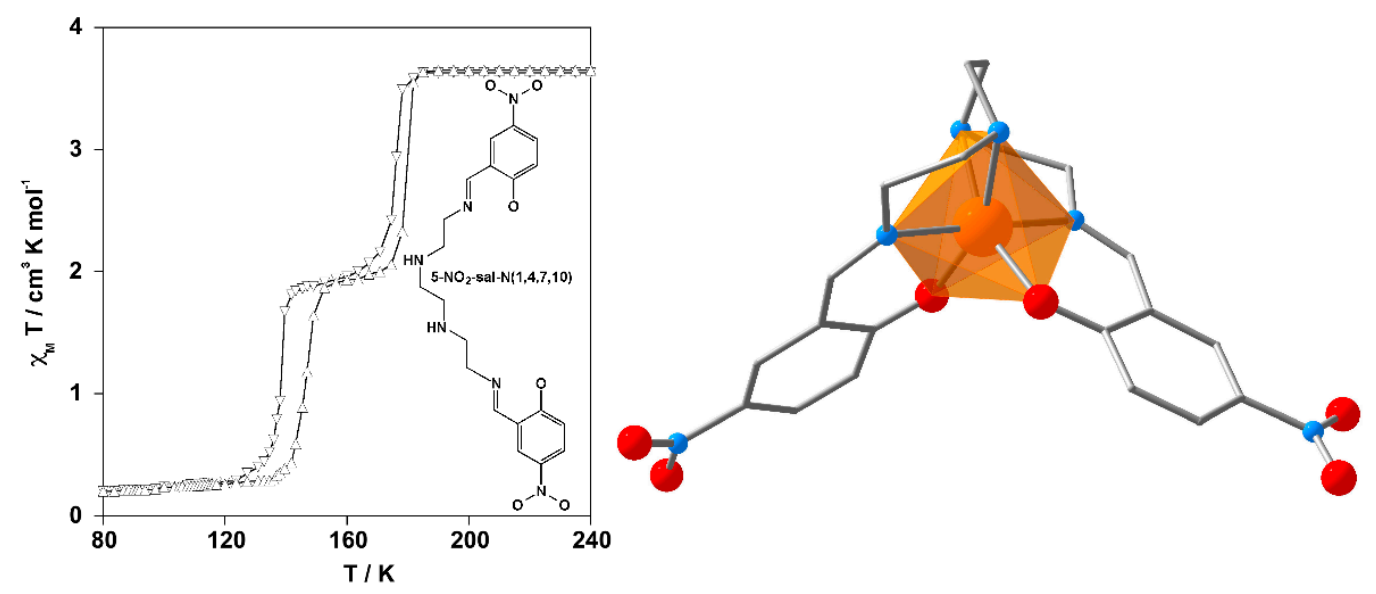

Figure 4. Spin crossover behavior of $\left[\mathrm{Fe}^{\mathrm{II}}\left\{5-\mathrm{NO}_{2}-\mathrm{sal}-\mathrm{N}(1,4,7,10)\right\}\right]$ (left) and molecular structure (right).

The first example of CSB involving change of space group was reported by Reger et al. for $\left\{\mathrm{Fe}\left[\mathrm{HC}\left(3,5-\mathrm{Me}_{2} \mathrm{pz}\right)_{3}\right]_{2}\right\}\left(\mathrm{BF}_{4}\right)_{2}$, where $\mathrm{HC}\left(3,5-\mathrm{Me}_{2} \mathrm{pz}\right)_{3}$ is the scorpionate-like tridentate ligand tris(3,5-dimethyl-1-pyrazolyl)methane. This compound undergoes an abrupt half SCO at $T_{\mathrm{C}}=204 \mathrm{~K}$. Above this temperature, where the HS crystal is monoclinic (space group $\mathrm{C} 2 / c$ ), the unit cell contains one independent $\mathrm{Fe}^{\mathrm{II}}$ site characterized by an average $\mathrm{Fe}-\mathrm{N}$ bond length $\mathrm{Fe}-\mathrm{N}^{\mathrm{av}}=2.164(3) \AA$. Below $204 \mathrm{~K}$, the crystal transforms into triclinic, its space group being $P \overline{1}$, with concomitant generation of a unit cell with two independent $\mathrm{Fe}^{\mathrm{II}}$ sites, one LS (Fe2-N $\mathrm{N}^{\mathrm{av}}=1.984(3) \AA$ ) and other HS $\left(\mathrm{Fe} 1-\mathrm{N}^{\mathrm{av}}=2.171(3) \AA\right)$. In this IP = 1HS-1LS, the cationic complexes with the same spin state, HS or LS, are arranged in layers parallel to the $a b$ plane. The HS and LS layers alternate along the $c$ axis (Figure 5) [38].
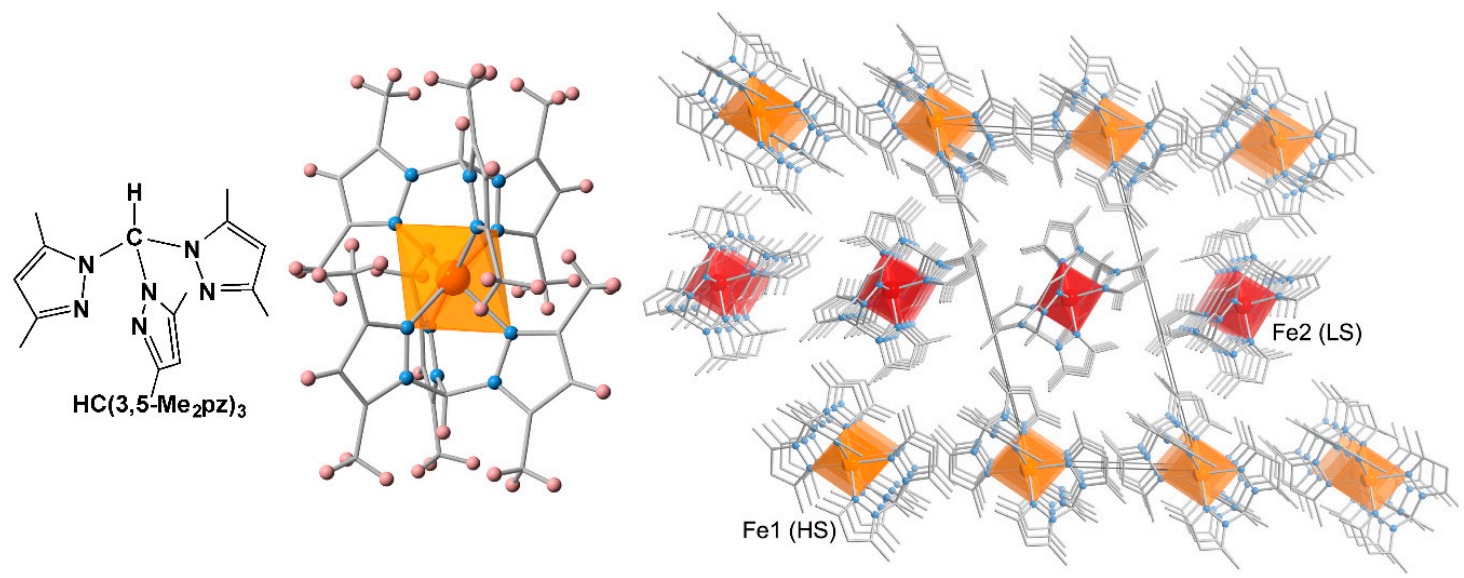

Figure 5. Molecular structure of the ligand $\left[\mathrm{HC}\left(3,5-\mathrm{Me}_{2} \mathrm{pz}\right)_{3}\right](\mathbf{l e f t})$ and $\left\{\mathrm{Fe}\left[\mathrm{HC}\left(3,5-\mathrm{Me}_{2} \mathrm{pz}\right)_{3}\right]_{2}\right\}^{2+}$ cation (middle). Projection of the crystal packing on the ac plane showing the ordering of the LS and HS layers $\left(\mathrm{BF}_{4}{ }^{-}\right.$anions have been removed) (right).

Matsumoto et al. have investigated in depth the SCO properties of an interesting series of complexes formulated $\left[\mathrm{Fe}^{\mathrm{II}}\left(\mathrm{H}_{3} \mathrm{~L}^{\mathrm{Me}}\right)_{2}\right](\mathrm{Cl})\left(\mathrm{XF}_{6}\right)$, where $\mathrm{H}_{3} \mathrm{~L}^{\mathrm{Me}}$ is the tripodal ligand 
tris[2-\{[(2-methyl-imidazoyl-4-yl)methylidene $]$ amino\}-ethyl $]$ amine (see Appendix) and $X=P, A s$. The $\mathrm{PF}_{6}{ }^{-}$derivative displays a half $\mathrm{SCO}\left(T_{\mathrm{C}}=122 \mathrm{~K}\right)$ accompanied by a change of space group from $P 2_{1} / n$ (HS state) to $P 2_{1}$ (IP state). In the pure HS state, there is one crystallographically independent $\mathrm{Fe}^{\mathrm{II}}$ site $\left(\mathrm{Fe}-\mathrm{N}^{\text {av }}=2.190(3) \AA\right.$ ), whereas in the IP the complex shows two equally populated $\mathrm{Fe}^{\mathrm{II}}$ sites, one HS $\left(\mathrm{Fe}-\mathrm{N}^{\mathrm{av}}=2.186(5) \AA\right)$ and other LS $\left(\mathrm{Fe}-\mathrm{N}^{\mathrm{av}}=1.994(5) \AA\right)$. A similar situation is observed when $\mathrm{PF}_{6}{ }^{-}$is formally replaced by $\mathrm{AsF}_{6}{ }^{-}$. Nevertheless, the resulting compound undergoes a two-step SCO centered at $T_{\mathrm{c} 2}=122 \mathrm{~K}$ and $T_{\mathrm{c} 1}=85 \mathrm{~K}$. The low-temperature step is incomplete due to slow HS $\leftrightarrow$ LS kinetics. In this step, when cooling at $1 \mathrm{~K} / \mathrm{min}, \chi_{\mathrm{M}} T$ drops from $1.70 \mathrm{~cm}^{3} \cdot \mathrm{K} \cdot \mathrm{mol}^{-1}$ at $100 \mathrm{~K}$ $(\mathrm{IP}=1 \mathrm{HS}-1 \mathrm{LS})$ down to $1.10 \mathrm{~cm}^{3} \cdot \mathrm{K} \cdot \mathrm{mol}^{-1}$ at $5 \mathrm{~K}$. However, after keeping the sample at $85 \mathrm{~K}$ for $12 \mathrm{~h}$ the $\mathrm{AsF}_{6}{ }^{-}$derivative relaxes completely to the LS state $\left(\chi_{\mathrm{M}} T\right.$ decreases down to $\left.0.24 \mathrm{~cm}^{3} \cdot \mathrm{K} \cdot \mathrm{mol}^{-1}\right)$. In this process the complex recovers the space group $P 2_{1} / n$. The crystal packing of both derivatives consists of two-dimensional networks constructed by $\mathrm{NH} \cdots \mathrm{Cl}^{-}$hydrogen bonds between $\mathrm{Cl}^{-}$and the imidazole $\mathrm{NH}$ groups of three neighboring $\left[\mathrm{Fe}^{\mathrm{II}} \mathrm{H}_{3} \mathrm{~L}^{\mathrm{Me}}\right]^{2+}$ cations, whereas $\mathrm{XF}_{6}-(X=\mathrm{P}, \mathrm{As})$ acts as an isolated anion filling the space between two consecutive supramolecular layers. The layers are racemic with the $\Delta$ and $\Lambda$ configurations of $\left[\mathrm{Fe}^{\mathrm{II}} \mathrm{H}_{3} \mathrm{~L}^{\mathrm{Me}}\right]^{2+}$ interconnected through hydrogen bonds in an alternating way. In the ordered IP the layers can be described as a stacking of chains of HS sites that alternate with chains of LS sites. Interestingly, the HS and LS sites adopt the $\Delta$ and $\Lambda$ configurations, respectively [39].

In the search for new $\mathrm{Fe}^{\mathrm{II}} \mathrm{SCO}$ complexes based on polydentate ligands with imidazole-pendant groups, the same research group has reported an important number of complexes of general formula $\left[\mathrm{Fe}\left(\mathrm{H}_{2} \mathrm{~L}^{2-M e}\right)_{2}\right](\mathrm{X})(\mathrm{Y})$. Solvent, where $\mathrm{H}_{2} \mathrm{~L}^{2-M e}$ is the tridentate ligand ((2-methylimidazol-4 -yl)methylidene)histamine. Among them the system $\left\{\left[\mathrm{Fe}\left(\mathrm{H}_{2} \mathrm{~L}^{2-M e}\right)_{2}\right](X)\left(\mathrm{ClO}_{4}\right) \cdot 1 \mathrm{EtOH}\right\}(X=\mathrm{Cl}, \mathrm{Br})$ shows a gradual two-step SCO behavior with $T_{\mathrm{c} 1}\left(T_{\mathrm{c} 2}\right)=75(255) \mathrm{K}$ for $X=\mathrm{Cl}^{-}$and $100(260) \mathrm{K}$ for $X=\mathrm{Br}^{-}$. The HS $\rightarrow$ IP transformation is accompanied by a change of the unit cell from monoclinic, space group $P 2_{1} / n$, to triclinic, space group $P \overline{1}$. For $X=B r$, the crystal structure of the IP confirms the occurrence of an ordering that can be described as made up of alternating undulated layers of LS or HS complexes (Figure 6). Interestingly, no re-entrant phase transition was observed in the LS state since the crystal remains $P \overline{1}[40]$.
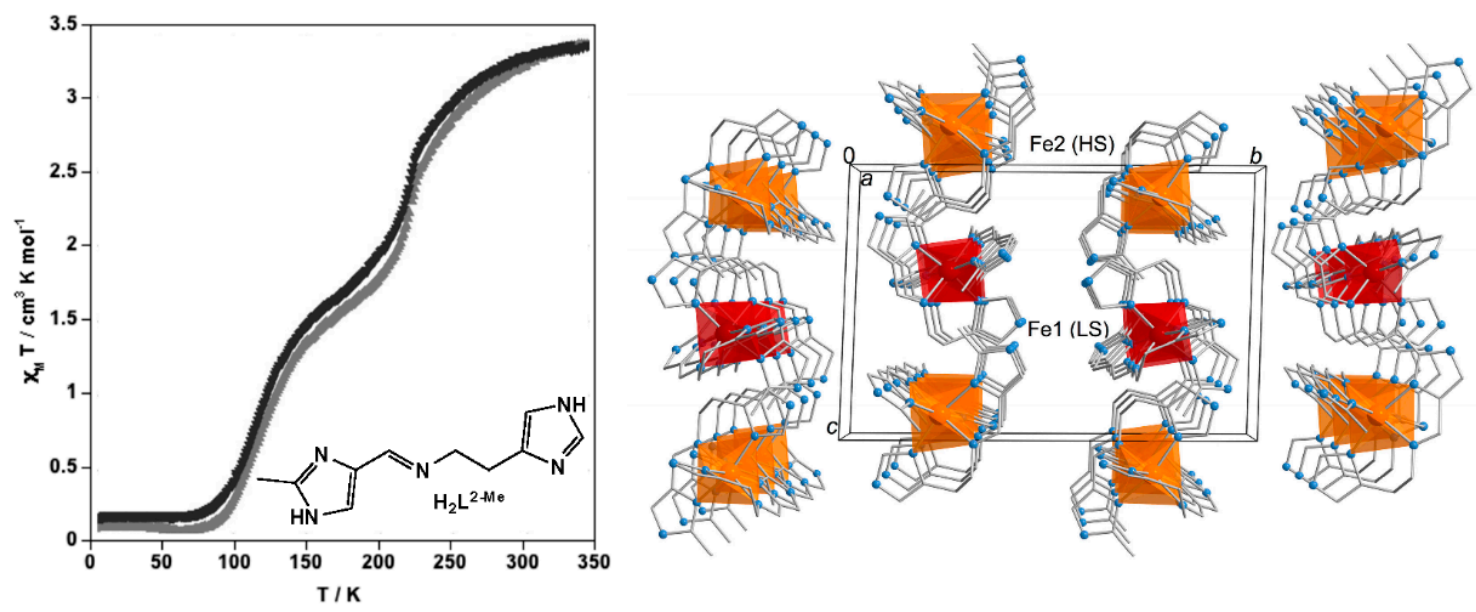

Figure 6. $\left\{\left[\mathrm{Fe}\left(\mathrm{H}_{2} \mathrm{~L}^{2-M e}\right)_{2}\right](\mathrm{X})\left(\mathrm{ClO}_{4}\right) \cdot 1 \mathrm{EtOH}\right\}:$ Spin crossover behavior for $\mathrm{X}=\mathrm{Cl}^{-}, \mathrm{Br}^{-}$(adapted with permission from Reference [40]) (left); and projection on the $a b$ plane of the crystal packing $\left(X=\mathrm{Br}^{-}\right)$ in the $\mathrm{IP}\left(\mathrm{Br}^{-}\right.$and $\mathrm{ClO}_{4}{ }^{-}$anions and $\mathrm{EtOH}$ have been removed) (right). Red and orange octahedrons correspond to LS and HS sites, respectively.

In the same line, Tuchagues and Collet et al. have reported the system $\left[\mathrm{Fe}^{\mathrm{II}}\left(\mathrm{H}_{2} \mathrm{~L}^{* 2-M e}\right)_{2}\right]\left(\mathrm{XF}_{6}\right)_{2}$ $(X=\mathrm{P}, \mathrm{As})$ derived from the acyclic hexadentate $\mathrm{N}_{6}$ Schiff base bis[N-(2-methylimidazol-4 -yl)methylidene-3-aminopropyl]ethylenediamine $\left(\mathrm{H}_{2} \mathrm{~L}^{* 2-M e}\right)$. The $\mathrm{AsF}_{6}-$ derivative undergoes an 
asymmetric two-step SCO behavior. At $250 \mathrm{~K}$, in the HS state, the crystal is orthorhombic (space group $\left.P 22_{1} 2_{1}\right)$ and contains one crystallographically independent $\mathrm{Fe}^{\mathrm{II}}$ site $\left(\mathrm{Fe}-\mathrm{N}^{\mathrm{av}}=2.187(3) \AA\right)$. At $100 \mathrm{~K}$, in the IP, the crystal retains the same unit cell but displays an unusual complex distribution of HS and LS sites. In the LS state $(T=15 \mathrm{~K})$, the crystal changes to $P 2{ }_{1} 2_{1} 2_{1}$ with concomitant quadrupling of the unit cell, which contains two independent $\mathrm{Fe}^{\mathrm{II}}$ sites $\left(\mathrm{Fe}-\mathrm{N}^{\mathrm{av}}=2.023(4) \AA\right)$ [41]. In contrast, the two-step transition of the $\mathrm{PF}_{6}{ }^{-}$derivative is practically symmetric. The high-temperature step is gradual $\left(T_{\mathrm{c} 2} \approx 155 \mathrm{~K}\right)$ while the low-temperature step $\left(T_{\mathrm{c} 1} \approx 97 \mathrm{~K}\right)$ is cooperative and exhibits a narrow hysteresis loop $6 \mathrm{~K}$ wide (Figure 7 ). At $250 \mathrm{~K}$, the unit cell $P 22_{1} 2_{1}$ contains two crystallographically identical $\left[\mathrm{Fe}^{\mathrm{II}}\left(\mathrm{H}_{2} \mathrm{~L}^{* 2-M e}\right)_{2}\right]^{2+}$ cations, which consistently with the magnetic data are $\mathrm{HS}\left(\mathrm{Fe}-\mathrm{N}^{\mathrm{av}}=2.190 \AA\right)$. At $110 \mathrm{~K}$, in the IP, the parameter $c$ doubles and the new unit cell $\left(P 2_{1}\right)$ contains four cations, two of which are crystallographically unique. One site is mainly HS $\left(\mathrm{Fe} 1-\mathrm{N}^{\mathrm{av}}=2.13(1) \AA\right)$, and the other is mainly LS (Fe2- $\left.\mathrm{N}^{\mathrm{av}}=2.04(1) \AA\right)$ (a rough estimate of the HS fraction on sites 1 (2) was found to be $75(25) \%$ ). The crystal packing is defined by layers of cations and layers of anions in the $a b$ plane alternating along $c$. Interestingly, in the IP $=1$ HS-1LS the ordering is defined by layers of cations that follow the pattern $\cdots$ HS-LS-LS-HS ... (Figure 7). In the pure LS state $(80 \mathrm{~K})$ the unit cell exhibits a new space group $\left(P 2{ }_{1} 2_{1} 2_{1}\right)$ defined by two independent LS complex cations [42].
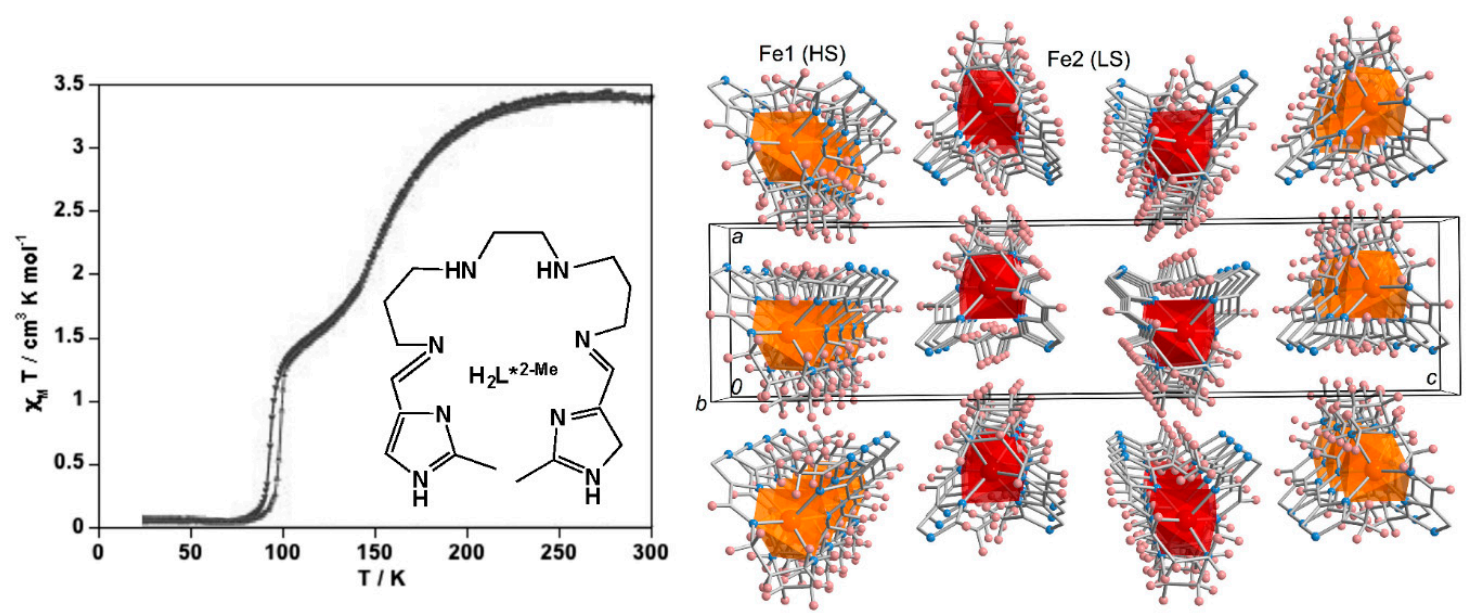

Figure 7. $\left[\mathrm{Fe}^{\mathrm{II}}\left(\mathrm{H}_{2} \mathrm{~L}^{* 2-M e}\right)_{2}\right]\left(\mathrm{PF}_{6}\right)_{2}$ : Spin crossover behavior (adapted with permission from Reference [42]) (left). Projection on the ac plane of the crystal packing in the IP showing the sequence of $\cdots$ HS-LS-LS-HS * . layers parallel to the $a b$ plane (the layers of $\mathrm{PF}_{6}{ }^{-}$have been removed); Red and orange octahedrons correspond to LS and HS sites (right).

An interesting example of asymmetric two-step SCO with CSB has been reported by Reedijk et al. for the complex [Fe(bapbpy)(NCS $\left.)_{2}\right]$, where bapbpy is the tetradentate ligand $\mathrm{N}-\left(6-\left(6-\left(\right.\right.\right.$ pyridin-2-ylamino)pyridin-2-yl)pyridin-2-yl)pyridin-2-amine. The $\chi_{M} T$ vs. $\mathrm{T}$ plot shows a high-temperature step centered at $T_{\mathrm{c} 2}=237 \mathrm{~K}$ involving $2 / 3$ of the HS centers, characterized by a hysteresis $4 \mathrm{~K}$ wide. The remaining $1 / 3$ of HS centers change to the LS state in a strong cooperative low-temperature transition centered at $T_{\mathrm{c} 1}=183 \mathrm{~K}$ with a hysteresis $22 \mathrm{~K}$ wide (Figure 8). The unit cell is monoclinic, space group $\mathrm{C2} / c$, and contains one independent $\mathrm{Fe}^{\mathrm{II}}$ site in the $\mathrm{HS}$ state. The molecules are held together through $\pi-\pi$ interactions and hydrogen bonds defining supramolecular chains running along the $c$-axis. In the IP, the crystal retains the same space group type but $c$ triples giving rise two independent $\mathrm{Fe}^{\mathrm{II}}$ sites, namely $1 \mathrm{HS}$ center and 2 equivalent LS centers (IP = 1HS-2LS), which display a $\cdots$ HS-LS-LS $\cdots$ ordering (Figure 8 ). In the LS state the crystal is triclinic, space group $C \overline{1}$, and contains one $\mathrm{Fe}^{\mathrm{II}}$ site. These steps are accompanied by unusually large overall enthalpy $\left(\Delta \mathrm{H}=26.7 \mathrm{~kJ} \cdot \mathrm{mol}^{-1} \cdot \mathrm{K}^{-1}\right)$ and entropy $\left(\Delta \mathrm{S}=125 \mathrm{~J} \cdot \mathrm{mol}^{-1} \cdot \mathrm{K}^{-1}\right)$ variations, which clearly account for the SCO and crystallographic phase transition contributions [43]. 


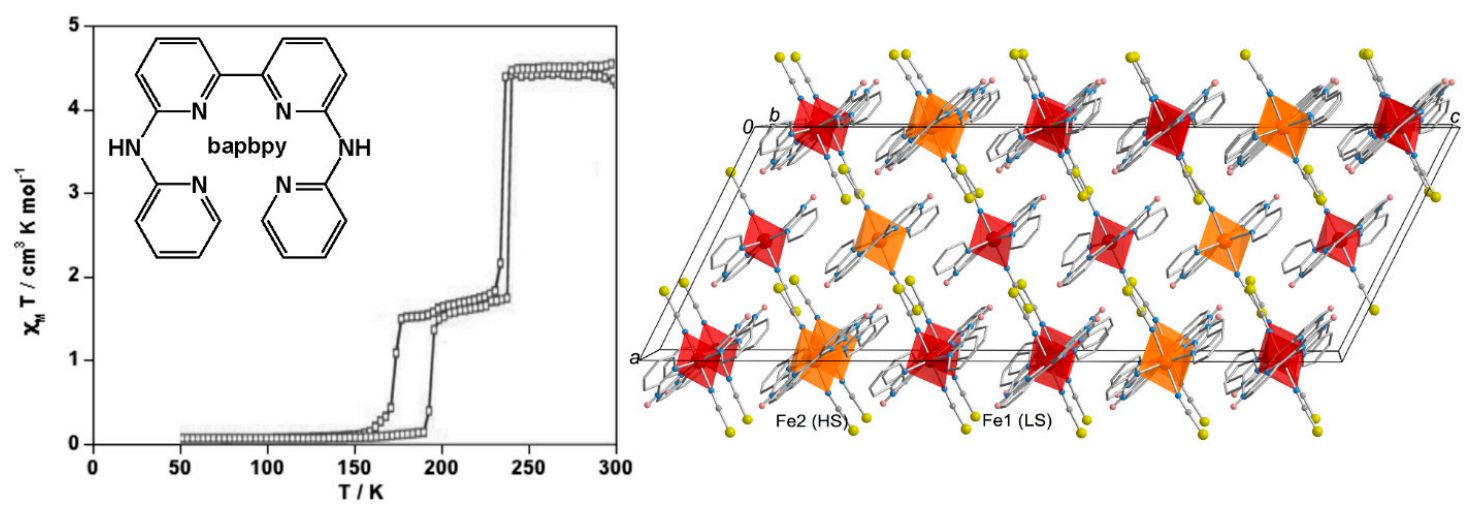

Figure 8. [Fe(bapbpy)(NCS) $)_{2}$ : Spin crossover behavior (adapted with permission from Reference [43]) (left); and projection on the ac plane of the crystal packing in the IP showing the LS-LS-HS sequence of molecules running along the $c$-axis. Red and orange octahedrons correspond to LS and HS sites, respectively (right).

\subsection{One-Step SCO Behavior}

So far, we have discussed a series of mononuclear complexes featuring two-step and half-step $\mathrm{SCO}$ with CSB and ordering. However, reversible CSB is not exclusive of systems undergoing stepwise transitions. Indeed, CSB has been reported for some mononuclear $\mathrm{Fe}^{\mathrm{II}}$ complexes exhibiting complete "one-step" SCO where obviously no IP exists. In this respect, Kahn et al. reported the complex $\left[\mathrm{Fe}(\mathrm{PMPA})_{2}(\mathrm{NCS})_{2}\right]\left(\mathrm{PMPA}=\mathrm{N}-\left(2^{\prime}\right.\right.$-pyridylmethylene)-4-(phenylethynyl)aniline, see Appendix $)$, which undergoes a cooperative SCO centered at $T_{\mathrm{C}}=212.5 \mathrm{~K}$ characterized by a hysteresis $37 \mathrm{~K}$ wide. The SCO is accompanied by a crystallographic phase transition between monoclinic, space group $P 2_{1} / c$, in the HS state and orthorhombic, space group Pccn, in the LS state. The molecules are located on two-fold axes in the LS state, while they lose this symmetry element in the HS state [44]. The complex $\left\{\mathrm{Fe}\left[\mathrm{H}_{2} \mathrm{~B}(\mathrm{pz})_{2}\right]_{2}\right.$ (phen)\} $\left(\left[\mathrm{H}_{2} \mathrm{~B}(\mathrm{pz})_{2}\right]_{2}{ }^{-}=\right.$dihydrobis(pyrazolyl)borate (Appendix); phen $=1,10$-phenanthroline) reported by Goeta and Real et al. illustrates another interesting example of CSB. It displays a cooperative SCO centered $T_{\mathrm{C}}=164 \mathrm{~K}$ with a hysteresis $4 \mathrm{~K}$ wide. In the HS state the crystal is monoclinic, $C 2 / c$, and changes to triclinic, $P \overline{1}$, in the LS state. Contrarily to that observed in the precedent example, the complex loses the two-fold axis when moving from the HS state to the LS state. Interestingly, in the photo-generated HS* state, the complex does not recover the two-fold axis, what constitutes a rare example photo-induced polymorphism [45].

Some $\mathrm{Fe}^{\mathrm{II}}$ complexes based on bispyrazolpyridine-ligands have been shown to exhibit $\mathrm{SCO}$ and CSB. For example, the complex $\left[\mathrm{Fe}(\mathrm{dmpp})_{2}\right]\left(\mathrm{ClO}_{4}\right)_{2}(\mathrm{dmpp}=2,6$-di $\{4$-methylpyrazol-1-yl $\}$ pyridine, see Appendix) reported by Howard, Halcrow and Létard et al. displays an abrupt SCO centered at $233 \mathrm{~K}$ with a hysteresis $3 \mathrm{~K}$ wide. The crystal is tetragonal, space group $P \overline{4} 2_{1} c$, in the HS state $(250 \mathrm{~K})$ and orthorhombic, space group $P 2{ }_{1}{ }_{1}{ }_{1} 2_{1}$, in the LS state $(30 \mathrm{~K})$ [46]. The related complex [Fe(dcpp $\left.)_{2}\right]\left(\mathrm{BF}_{4}\right)_{2}$ (dcpp = 2,6-bis(4-chloro-1H-pyrazol-1-yl)pyridine, see Appendix), by Halcrow et al., displays a similar SCO behavior. This complex changes reversibly from $P \overline{4} 2_{1} c$ (HS state) to the $P 2_{1}$ (LS state) [47]. The polymorph A of the related complex $\left[\mathrm{Fe}(4-\mathrm{epp})_{2}\right]\left(\mathrm{BF}_{4}\right)_{2}$ (4-epp = 2,6-di $\{4$-methylpyrazol-1-yl $\}$ pyridine, see Appendix), reported by Ruben et al., undergoes an abrupt SCO centered at $T_{\mathrm{C}}=341 \mathrm{~K}$ featuring a hysteresis $8 \mathrm{~K}$ wide and a reversible crystallographic phase transition between the space groups $P 22_{1} 2_{1} 2_{1}$ (HS state) and Pbcn (LS state) [48]. The complex [Fe(3-bpp $\left.)_{2}\right]\left[\mathrm{Fe}(\mathrm{CN})_{5}(\mathrm{NO})\right](3-\mathrm{bpp}=$ 2,6-di(1H-pyrazol-3-yl)pyridine, see Appendix), reported by Goodwin et al., undergoes a cooperative SCO centered at $182 \mathrm{~K}$ accompanied by a change from tetragonal, space group P4/ $\mathrm{ncc}$, in the HS state to the orthorhombic, space group Pnca, in the LS state [49].

Within the family of imidazole-based Fe ${ }^{\mathrm{II}} \mathrm{SCO}$ complexes, Bréfuel and Matsumoto $e t$ al. have found that the perchlorate salt of the aforementioned complex $\left[\mathrm{Fe}^{\mathrm{II}}\left(\mathrm{H}_{2} \mathrm{~L}^{* 2-M e}\right)_{2}\right]^{2+}$ displays a strong 
cooperative spin transition centered at $T_{\mathrm{c}}=171.5 \mathrm{~K}$ featuring a hysteresis loop $c a .5 \mathrm{~K}$ wide and simultaneous crystallographic phase transition between the space groups $P 2_{1} / n$ (HS) and $P 2_{1}$ (LS) [50].

Linert et al. have reported the complex $\left[\mathrm{Fe}(\mathrm{i} 4 \mathrm{tz})_{6}\right]\left(\mathrm{SbF}_{6}\right)_{2}(\mathrm{i} 4 \mathrm{tz}=1$-isobuthyl-1H-tetrazole), which undergoes a gradual SCO in the temperature interval $60-160 \mathrm{~K}$ with $T_{\mathrm{C}}=116 \mathrm{~K}$ and a crystallographic phase transition. At $200 \mathrm{~K}$, the crystal is triclinic, $P \overline{1}$, and contains one crystallographically independent $\mathrm{Fe}^{\mathrm{II}}$ site, located on an inversion center. The average Fe- $\mathrm{N}^{\text {av }}$ bond length, 2.189(5) $\AA$, is consistent with a fully populated HS state in agreement with the magnetic data. Upon cooling at $100 \mathrm{~K}$, where the HS molar fraction is about $37 \%$, the space group type remains the same, but the volume of the unit cell triples. The new unit cell contains two different $\left[\mathrm{Fe}(\mathrm{i} 4 \mathrm{tz})_{6}\right]^{2+}$ centers with average bond lengths, Fe1- $\mathrm{N}^{\mathrm{av}}=2.187(7) \AA$ and $\mathrm{Fe} 2-\mathrm{N}^{\mathrm{av}}=2.175(7) \AA$, typical of the $100 \%$ populated HS state [51].

\section{Polynuclear Iron(II) Complexes}

In the late 1980s Kahn introduced the idea of coupling two $\mathrm{Fe}^{\mathrm{II}}$ centers through suitable bridging ligands as a way to modulate the SCO behavior by means of magnetic and/or elastic interactions [52]. Kahn and Zarembovitch et al. reported some years later the dinuclear complex $\left\{\left[\mathrm{Fe}(\mathrm{bt})(\mathrm{NCS})_{2}\right]_{2}(\mu\right.$-bpym $\left.)\right\}$ (bt $=2,2^{\prime}$-bithiazoline and bpym = bipyrimidine, see Appendix), which became a new paradigm of two-step SCO $(2 \mathrm{~d},[53,54])$. It was suggested that this two-step transition reflects the transformation between the three possible "spin-pair" states of the dinuclear species, i.e., LS-LS $\leftrightarrow$ LS-HS $\leftrightarrow$ HS-HS. In a subsequent collaborative work Real, Gütlich, Bousseksou, Collet and coworkers confirmed, from Mössbauer and Raman spectroscopies and crystallographic investigations combined with LIESST effect, the selective transformation between the "spin-pair" states in the bpym-bt dinuclear species [55-59]. Unfortunately, no direct evidence of the IP = 1HS-1LS state could be obtained, since the crystal structure of this complex in the IP state is an average of the HS and LS states.

The interesting properties of the bpym-bt derivative motivated the search for new dinuclear SCO complexes [60]. In this context, Kaizaki et al. reported a new singular dinuclear complex $\left\{\left[\mathrm{Fe}^{\mathrm{II}}\left(\mathrm{NCBH}_{3}\right)\right.\right.$ (4-phpy) $\left.]_{2}(\mu \text {-bpypz })_{2}\right\}$ (bpypz $=3,5$-bis(2-pyridyl)-pyrazolate and 4phpy $=4$-phenylpyridine). This compound does not follow the aforementioned transformation between "spin-pair" states. The magnetic properties show the occurrence of a gradual two-step SCO with a plateau centered at ca. $200 \mathrm{~K}$ (Figure 9). According to the magnetic data, the crystal structure was investigated at $296 \mathrm{~K}$, $200 \mathrm{~K}$ and $100 \mathrm{~K}$ where, respectively, states HS-HS, LS-HS and LS-LS should be completely populated. At $296 \mathrm{~K}$ and $100 \mathrm{~K}$, the crystal is triclinic, $P \overline{1}$, and contains one crystallographically independent $\mathrm{Fe}^{\mathrm{II}}$ site with Fe-N bond lengths typical of the HS and LS states, respectively. At $200 \mathrm{~K}$ the space group type remains the same, but the volume of the unit cell doubles to accommodate two $\mathrm{Fe}^{\mathrm{II}}$ sites, one $\mathrm{HS}$ and the other LS. However, the HS and LS sites belong to different dinuclear molecules and consequently, the IP is made up of HS-HS and LS-LS dinuclear species defining a $\cdots$ HS-HS $\cdots$ LS-LS $\cdots$ pattern. The dimers interact each other via strong $\pi-\pi$ intermolecular interactions through the 4-phpy ligands. These intermolecular interactions extend in two dimensions defining layers (Figure 9). The authors consider that compared to the bpym-bt system, the more rigid nature of the tetradentate $\mu$-bpypz ${ }^{-}$ ligand and the strong $\pi-\pi$ intermolecular interactions developed in the crystal, favour the generation of HS-HS and LS-LS spin-pairs instead of the LS-HS ones in the IP [61].

The first dinuclear complex with an ordered IP = LS-HS was reported by Brooker and Murray et al. for the complex $\left[\mathrm{Fe}^{\mathrm{II}}(\mathrm{PMAT})\right]_{2}\left(\mathrm{BF}_{4}\right)_{4}$. DMF (PMAT is a 1,2,4-triazole based acyclic tetradentate ligand). Magnetic and Mössbauer studies show that this dinuclear complex undergoes a half SCO behavior. At $298 \mathrm{~K}$, the asymmetric unit is made up of one half of the dinuclear complex with the other half generated by a center of inversion. The average bond length $\mathrm{Fe}^{\mathrm{II}}-\mathrm{N}^{\mathrm{av}}=2.188(5) \AA$ is characteristic of the HS state. However, at $123 \mathrm{~K}$, the asymmetric unit contains a complete dimeric unit with two independent $\mathrm{Fe}^{\mathrm{II}}$ centers, one $\mathrm{HS}\left(\mathrm{Fe}^{\mathrm{II}}-\mathrm{N}^{\text {av }}=2.202(4) \AA\right)$ and the other $\mathrm{LS}\left(\mathrm{Fe}^{\mathrm{II}}-\mathrm{N}^{\text {av }}=1.998(4) \AA\right)$ (Figure 10). The HS-HS $\rightarrow$ HS-LS transition involves doubling of the triclinic, $P \overline{1}$, unit cell [62]. Further evidence confirming the prevalence of the LS-HS state in $\mathrm{Fe}^{\mathrm{II}}$ dinuclear SCO complexes 
was found by Kepert and Murray et al. for the complex $\left[\mathrm{Fe}_{2}(\mathrm{ddpp})_{2}(\mathrm{NCS})_{4}\right] \cdot 4 \mathrm{CH}_{2} \mathrm{Cl}_{2}(\mathrm{ddpp}=2,5-\mathrm{di}$ $\left(2^{\prime}, 2^{\prime \prime}\right.$-dipyridylamino)pyridine, see Appendix). This compound displays a gradual two-step SCO with $T_{\mathrm{c} 2}=180 \mathrm{~K}$ and at $T_{\mathrm{c} 1}=80 \mathrm{~K}$ separated by a plateau $\mathrm{ca}$. $30 \mathrm{~K}$ wide in the temperature interval $140-110 \mathrm{~K}$. The crystal structure investigated at $250 \mathrm{~K}, 123 \mathrm{~K}$ and $25 \mathrm{~K}$ confirmed the presence of the HS-HS, LS-HS and LS-LS states, respectively. The crystal is triclinic, its space group being $P \overline{1}$, but in contrast the asymmetric unit contains two independent $\mathrm{Fe}^{\mathrm{II}}$ sites at all temperatures. Consequently, no CSB occurs in this system [63].
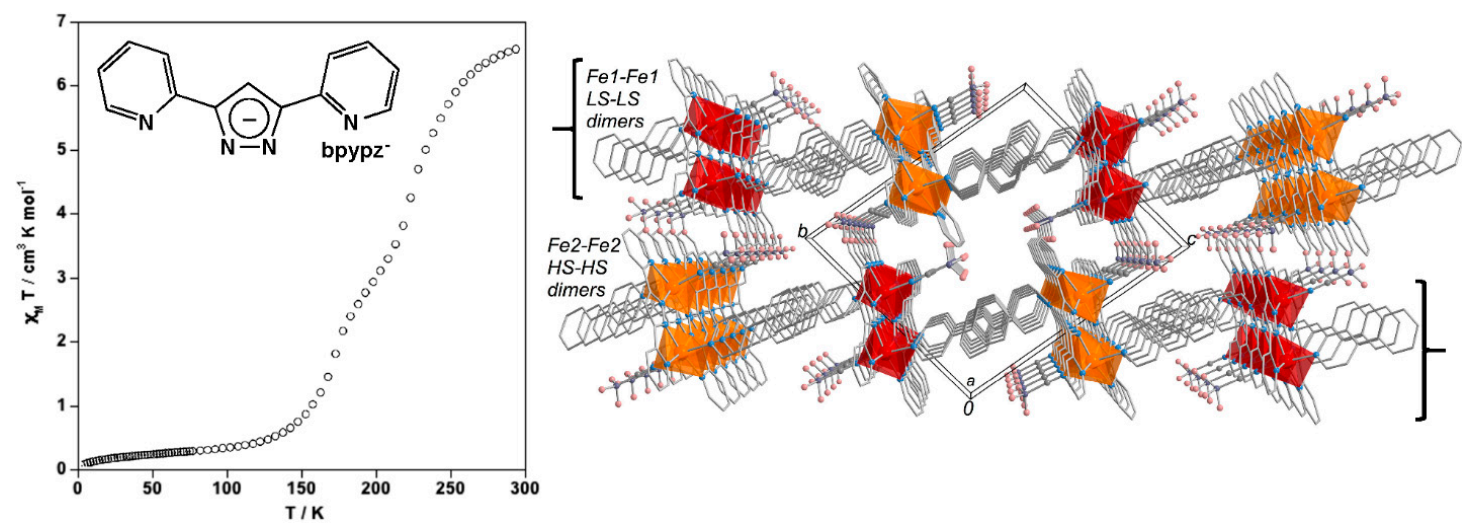

Figure 9. $\left\{\left[\mathrm{Fe}^{\mathrm{II}}\left(\mathrm{NCBH}_{3}\right)(4-\mathrm{phpy})\right]_{2}(\mu \text {-bpypz })_{2}\right\}$ : Spin crossover behavior (adapted with permission from Reference [61]) (left); and projection on the $b c$ plane of the crystal packing displaying the LS-LS ...HS-HS order of the dimers in the IP (right). Red and orange octahedrons correspond to LS and HS sites, respectively.

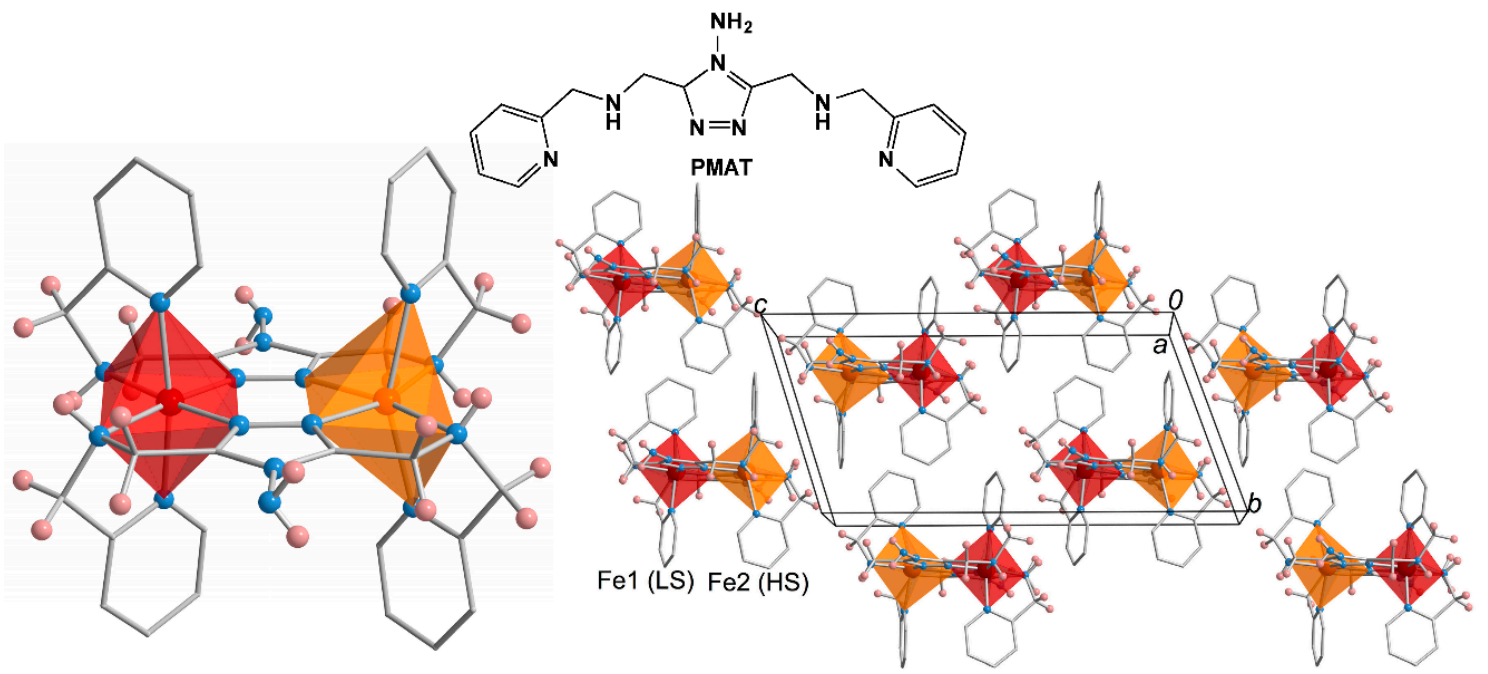

Figure 10. Molecular structure of a dimeric $\left\{\left[\mathrm{Fe}^{\mathrm{II}}(\mathrm{PMAT})\right]_{2}\right\}^{4+}$ unit (left) and projection of the unit cell on $b c$ (right) $\left(\mathrm{BF}_{4}{ }^{-}\right.$anions and DMF inclusions have been omitted). Red and orange octahedrons correspond to LS and HS sites, respectively.

The complex $\left\{\left[\mathrm{Fe}(3-\mathrm{bpp})(\mathrm{NCS})_{2}\right]_{2}\left(4,4^{\prime}\right.\right.$-bipyridine $) \cdot 2 \mathrm{CH}_{3} \mathrm{OH}$ (3-bpp $=2,6$-bis(pyrazol-3-yl) pyridine) reported by Létard, Rosa and Guionneau et al. affords another example of half SCO behavior and CSB in a dinuclear unit. In the temperature interval $250-120 \mathrm{~K}, \chi_{M} T$ is equal to $7.2 \mathrm{~cm}^{3} \cdot \mathrm{K} \cdot \mathrm{mol}^{-1}$ and consistent with two $\mathrm{Fe}^{\mathrm{II}}$ centers in the HS state. Below $120 \mathrm{~K}, \chi_{\mathrm{M}} T$ gradually drops to $4.7 \mathrm{~cm}^{3} \cdot \mathrm{K} \cdot \mathrm{mol}^{-1}$, a value $\mathrm{ca} .15 \%$ higher than expected for a half $\mathrm{SCO}$ (Figure 11). Below $70 \mathrm{~K}$, no further spin conversion occurs, most probably due to kinetic effects. The unit cell is monoclinic, 
its space group being $P 2_{1} / n$, with an inversion center located on the $4,4^{\prime}$-bipy bridge (phase I). This structure, characterized by one independent $\mathrm{HS} \mathrm{Fe}^{\mathrm{II}}$ site, is stable in the temperature interval $298-120 \mathrm{~K}$. At $c a .115 \mathrm{~K}$, a crystallographic phase transition coincides with the onset of the SCO. Consequently, in the new Cc space group the unit cell volume quadruples, and contains four crystallographically independent $\mathrm{HS} \mathrm{Fe}^{\mathrm{II}}$ centers segregated in two distinct dinuclear units (phase II). At $30 \mathrm{~K}$, where $\chi_{\mathrm{M}} T$ is consistent with a 1:1 mixture of HS and LS states, the crystal is triclinic, $P \overline{1}$, and the unit cell volume halves. Despite this, the unit cell contains two distinct asymmetric dinuclear units displaying a LS-HS state (phase III) [64,65].
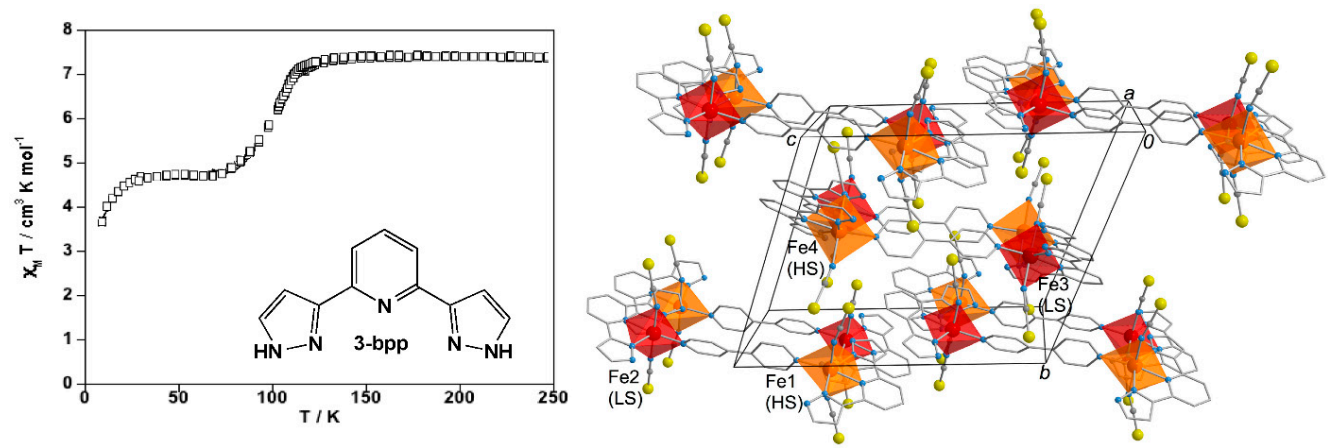

Figure 11. $\left\{\left[\mathrm{Fe}(3-\mathrm{bpp})(\mathrm{NCS})_{2}\right]_{2}\left(4,4^{\prime}\right.\right.$-bypiridine $\left.)\right\} \cdot 2 \mathrm{CH}_{3} \mathrm{OH}$ : Spin crossover behavior (adapted with permission from Reference [64]) (left); and projection on the $b c$ plane the crystal packing in the IP $\left(\mathrm{CH}_{3} \mathrm{OH}\right.$ has been omitted) (right). Red and orange octahedrons correspond to LS and HS sites, respectively.

\section{Polymeric Iron(II) Complexes}

\subsection{One-Dimensional Complexes}

As far as we know the complex [FeL1(azpy)] reported by Weber et al., represents the only example of one-dimensional polymeric SCO displaying an ordered IP state and CSB (L1 is the tetradentate Schiff-like base \{diethyl(E,E)-2,2'-[1,2-phenyl-bis(iminomethylidyne)]bis[3-oxobutanoate]-(2-)- $\left.\mathrm{N}, \mathrm{N}^{\prime}, \mathrm{O}^{3}, \mathrm{O}^{3 \prime}\right\}$ and azpy is the bismonodentate bridging ligand $4,4^{\prime}$-azopyridine). The magnetic behavior of this complex shows a complete two-step transition with steps, centered at $T_{\mathrm{c} 2}=326 \mathrm{~K}$ and $T_{\mathrm{c} 1}=152 \mathrm{~K}$, separated by a large plateau (IP). The crystal structure was solved in the IP, at $200 \mathrm{~K}$, where the crystal is orthorhombic, space group $P 2{ }_{1} 2_{1} 2_{1}$, and displays a perfect ordering HS-LS along the chains (Figure 12). In the LS state, the crystal changes to monoclinic $P 2{ }_{1}(130 \mathrm{~K})$ but, unfortunately, complete analysis of the structure could not be performed due to twinning during the phase transition [66].
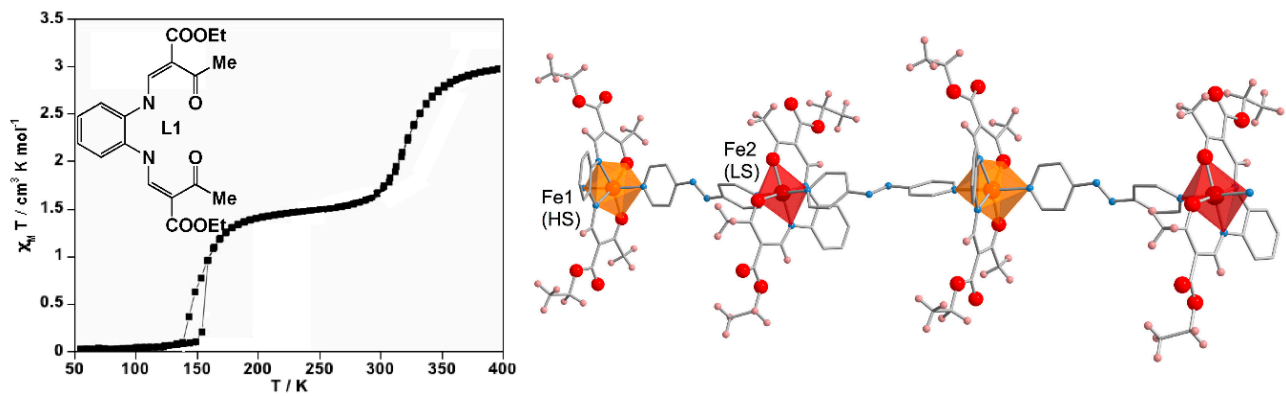

Figure 12. [FeL1(azpy)]: Spin crossover behavior (adapted with permission from Reference [66]) (left); and fragment of a chain displaying the alternate order 1HS-1LS in the IP at $200 \mathrm{~K}$ (right). Red and orange octahedrons correspond to LS and HS sites, respectively. 
Haasnoot and Gamez et al. have reported the $1 \mathrm{D}$ coordination polymer [Fe(btzx) $\left.)_{3}\right]\left[\mathrm{CF}_{3} \mathrm{SO}_{3}\right]_{2} \cdot \mathrm{CH}_{3} \mathrm{CN}$, (btzx = m-xylylenebis(tetrazole), see Appendix), a singular example in which SCO and crystallographic phase transition do not occur simultaneously. Apparently, the crystallographic phase transition predisposes the system to exhibit a half SCO. This compound crystallizes in the hexagonal space group $P 6_{3} / m$. However, it changes to the trigonal space group $P \overline{3}$ at $170 \mathrm{~K}$. In the hexagonal phase there is one independent $\mathrm{Fe}^{\mathrm{II}}$ site, which is $\mathrm{HS}$, while the trigonal phase is characterized by the presence of four crystallographically independent $\mathrm{Fe}^{\mathrm{II}} \mathrm{HS}$ sites distributed in two distinct chains. The chain 1 runs along a $C_{3}$ axis and contains the sites $\mathrm{Fe}_{1}$ and $\mathrm{Fe}_{2}$ with $\mathrm{Fe}-\mathrm{N}^{\text {av }}$ bond lengths 2.193(4) $\AA$ and 2.192(4) $\AA$, respectively. Chain 2 is on a $S_{6}$ symmetry with $\mathrm{Fe}_{3}$ $\left(\mathrm{Fe}-\mathrm{N}^{\mathrm{av}}=2.178(4) \AA\right)$ and $\mathrm{Fe}_{4}\left(\mathrm{Fe}-\mathrm{N}^{\mathrm{av}}=2.185(4) \AA\right)$ sites. Below $150 \mathrm{~K}$, the $\mathrm{Fe}_{2}$ and $\mathrm{Fe}_{4}$ centers undergo a gradual SCO $\left(T_{\mathrm{C}}=110 \mathrm{~K}\right)$ generating an ordered IP $=1 \mathrm{HS}-1 \mathrm{LS}$ [67].

\subsection{Two-Dimensional Coordination Polymers}

The compound $\left[\mathrm{Fe}_{2}\left(2,2^{\prime} \text {-bipyridine)(imidazolate }\right)_{4}\right]$ reported by Reiff, Storr, and Thompson et al. is a singular coordination polymer constituted of extended 2D double-layer sheets of alternating tetrahedral and octahedral $\mathrm{Fe}^{\mathrm{II}}$ centers. The tetrahedral $\mathrm{Fe}^{\mathrm{II}}$ centers are surrounded by four imidazolate ligands, which bridge to four other $\mathrm{Fe}^{\mathrm{II}}$. The hexacoordinate $\mathrm{Fe}^{\mathrm{II}}$ centers complete their coordination sphere with a 2,2'-bipyridine ligand. This compound undergoes two structural phase transitions centered at $T_{\mathrm{c} 2}=151$ and $T_{\mathrm{c} 1}=135 \mathrm{~K}$ defining three phases $(\alpha, \beta$, and $\gamma)$. The high-temperature phase, $\alpha$, is consistent with $100 \% \mathrm{Fe}^{\mathrm{II}}$ centers in the HS state $\left(\chi_{\mathrm{M}} \mathrm{T}=3.4 \mathrm{~cm}^{3} \cdot \mathrm{K} \cdot \mathrm{mol}^{-1}\right)$, the transition to the intermediate phase, $\beta$, features a very limited change of $\chi_{M} T(c a .3 \%)$, while the subsequent transformation to the low temperature phase, $\gamma$, involves a variation of $\chi_{\mathrm{M}} T \mathrm{ca}$. $16 \%$ characterized by a thermal hysteresis loop $4 \mathrm{~K}$ wide. The three phases are triclinic, $P \overline{1}$, but the volume of the unit cell becomes 6 times larger when the system moves from the $\alpha$ phase to the $\beta$ phase and, then, reduces to the half when the $\beta$ phase transforms into the $\gamma$ phase. In the $\gamma$ phase there are six crystallographically independent $\mathrm{Fe}^{\mathrm{II}}$ sites (three octahedrons and three tetrahedrons). In perfect agreement with the magnetic and Mössbauer data, the crystal structure of the $\gamma$ phase shows that only one octahedrally coordinate $\mathrm{Fe}^{\mathrm{II}}$ site is LS while the other five sites remain in the HS state [68].

Kepert et al. have reported the doubly interpenetrated 2D porous coordination polymer [Fe(bpe $\left.)_{2}(\mathrm{NCS})_{2}\right] \cdot 3$ (acetone), (bpe is 1,2-bis(4-pyridyl)ethane, see Appendix), which undergoes a complete two-step SCO. Above $155 \mathrm{~K}$, a constant $\chi_{\mathrm{M}} T$ value, $c a .3 .2 \mathrm{~cm}^{3} \cdot \mathrm{K} \cdot \mathrm{mol}^{-1}$, characterizes the HS state while below $60 \mathrm{~K}$ the compound is essentially LS $\left(\chi_{\mathrm{M}} T \approx 0.35 \mathrm{~cm}^{3} \cdot \mathrm{K} \cdot \mathrm{mol}^{-1}\right)$. The two half SCO, separated by a plateau $20 \mathrm{~K}$ wide $\left(\chi_{\mathrm{M}} T\right.$ centered at $\left.1.6 \mathrm{~cm}^{3} \cdot \mathrm{K} \cdot \mathrm{mol}^{-1}\right)$, occurs at $T_{\mathrm{c} 2}=133 \mathrm{~K}$ and $T_{\mathrm{c} 1}=80 \mathrm{~K}$. In the HS state, there are two independent $\mathrm{Fe}^{\mathrm{II}}$ sites with distinct angular distortions and $\mathrm{Fe}-\mathrm{N}$ values. Upon cooling, the less distorted HS site changes to the LS state, thereby generating a 1HS-1LS checkerboard-like arrangement in the plateau (IP). This structural reorganization occurs without crystallographic phase transition. However, upon further cooling, the low-temperature step 1HS-1LS $\rightarrow$ LS occurs simultaneously with a crystallographic phase transition from the orthorhombic space group $P 22_{1} 2_{1} 2$ to the tetragonal space group $P \overline{4} 2_{1} c$ [69]. In a related system, Real et al. have recently reinvestigated the related porous coordination polymer $\left[\mathrm{Fe}(\operatorname{tvp})_{2}(\mathrm{NCS})_{2}\right] \cdot$ Guest (tvp $=\operatorname{trans}\left(4,4^{\prime}\right.$-vinylenedi-pyridine, see Appendix). This compound is made up of perpendicular interpenetration of two identical stacks of $\left[\mathrm{Fe}(\mathrm{tvp})_{2}(\mathrm{NCS})_{2}\right]_{\mathrm{n}}$ layers, which define large square-sectional channels where the guest molecules are located. The magnetic and calorimetric data indicate a guest-dependent SCO behavior accompanied by crystallographic phase transition in the temperature interval 170-215 K. In particular, for Guest $=2$. benzonitrile and $4 \mathrm{CH}_{3} \mathrm{CN} \cdot 4 \mathrm{H}_{2} \mathrm{O}$, the crystallographic phase transition occurs between the tetragonal space group P4/ncc in the HS state and the orthorhombic space group Pccn in the LS state. In addition to the spin-state change, this phase transition features a change of the angle of interpenetration of the $\left[\mathrm{Fe}(\mathrm{tvp})_{2}(\mathrm{NCS})_{2}\right]_{n}$ layers from strictly orthogonal in the HS state to oblique in the LS state [70]. 
Adams and Real et al. have reported a series of compounds formulated $\left[\mathrm{Fe}\left(4,4^{\prime} \text {-bipy }\right)_{2}(\mathrm{NCX})_{2}\right]$. Guest $\left(4,4^{\prime}\right.$-bipy $=4,4^{\prime}$-bipyridine, $X=\mathrm{S}$, Se), which are closely related to the two precedent examples. However, the slightly shorter length of the bridging ligand 4,4'-bipy with respect to the ligands bpe and tvp prevents interpenetration of the coordination polymer $\left[\mathrm{Fe}\left(4,4^{\prime} \text {-bipy }\right)_{2}(\mathrm{NCX})_{2}\right]$ and, consequently, the crystal is constituted of a parallel stack of layers. Nevertheless, the space between the layers can be filled with different guest solvent molecules. For Guest $=4 \mathrm{CHCl}_{3}$, the $\mathrm{S}$ derivative experiences a cooperative $\mathrm{SCO}$ with two steps centered at $T_{\mathrm{c} 2}=146.9 \mathrm{~K}$ and $T_{\mathrm{c} 1}=101.7 \mathrm{~K}$ ) and hysteresis loops $6.6 \mathrm{~K}$ and $21 \mathrm{~K}$ wide, respectively (Figure 13). The corresponding Se derivative undergoes a cooperative half SCO centered at $T_{\mathrm{C}}=165 \mathrm{~K}$ characterized by a hysteresis $6.6 \mathrm{~K}$ wide. For both derivatives, the high-temperature HS $\rightarrow$ 1HS-1LS step is accompanied by a crystallographic phase transition from the space group $C 2 / c$ to the space group $P 2 / c$ affording an ordered checkerboard like arrangement. The low-temperature step for the $S$ derivative presumably involves a re-entrant crystallographic phase transition from IP $=1 \mathrm{HS}-1 \mathrm{LS}(P 2 / c)$ phase to the LS $(\mathrm{C} 2 / c)$ phase [71].
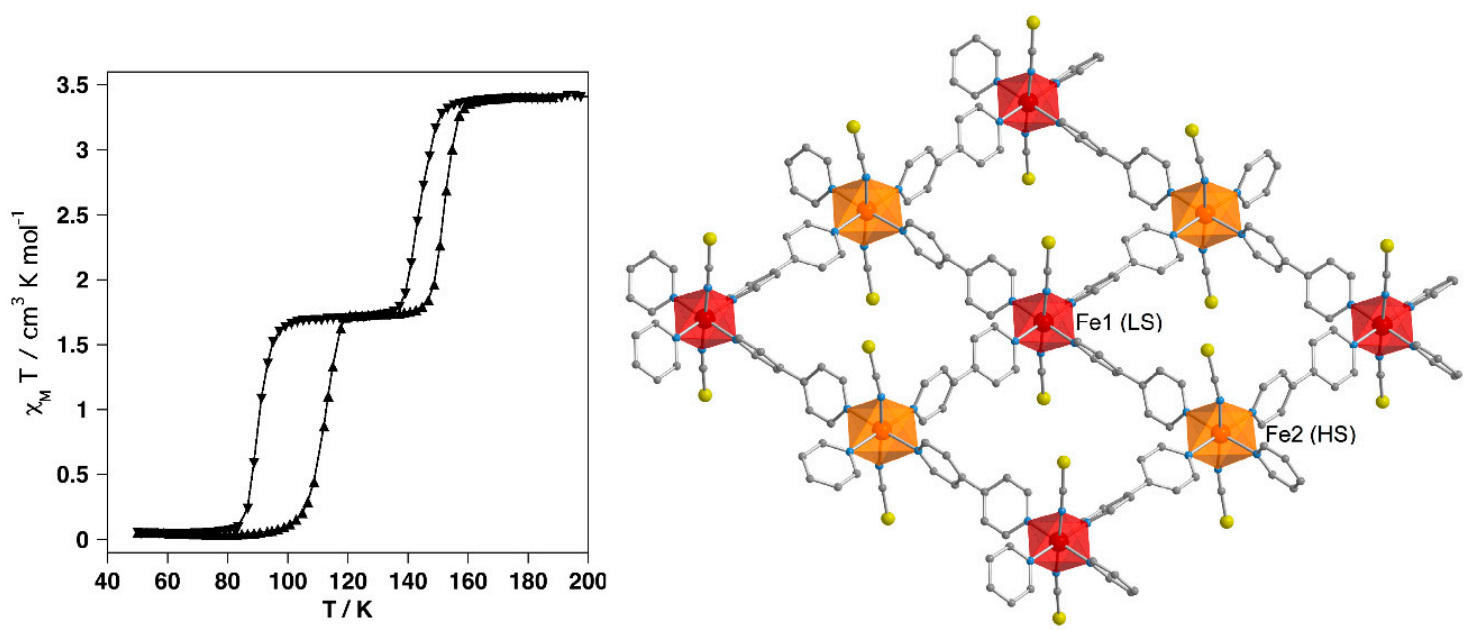

Figure 13. $\left[\mathrm{Fe}\left(4,4^{\prime} \text {-bipy }\right)_{2}(\mathrm{NCS})_{2}\right] \cdot 4 \mathrm{CHCl}_{3}$ : Spin crossover behavior (left); and perspective view of a layer displaying the checkerboard 1HS-1LS order in the IP at $120 \mathrm{~K}$ (right). Red and orange octahedrons correspond to LS and HS sites, respectively.

Chen and Zhang et al. have reported the homoleptic two-dimensional coordination polymer $\left[\mathrm{Fe}(\mathrm{bdpt})_{2}\right] \cdot \mathrm{nSolvent}$ where $\mathrm{nSolvent}=$ unsolvate, $1 \mathrm{EtOH}$ and $1 \mathrm{MeOH}$, and bdpt is the conjugate base of the ionogenic bridging ligand 3-(5-Bromo-2-pyridyl)-5-(4-pyridyl)-1,2,4-triazol. The three derivatives undergo a cooperative two-step SCO involving a 50\% mixture of HS and LS centers in the plateau. For the unsolvated compound, the two transitions take place without hysteresis at $T_{\mathrm{c} 2}=192 \mathrm{~K}$ and $T_{\mathrm{c} 1}=143.5 \mathrm{~K}$. The inclusion of $\mathrm{MeOH}(\mathrm{EtOH})$ induces an average downshift of $T_{\mathrm{c} 2}$ and $T_{\mathrm{c} 1}$ of $18 \mathrm{~K}$ and $10.5 \mathrm{~K}$ ( $36 \mathrm{~K}$ and $26.5 \mathrm{~K}$ ), respectively, (Figure 14). This decrease of $T_{\mathrm{c}}$ is accompanied by a slight increase of cooperativity, which is specially pronounced for the $\mathrm{EtOH}$ derivative. In the HS state, the unit cell is monoclinic, space group $P 2_{1} / n$, and contains one independent $\mathrm{Fe}^{\mathrm{II}}$ site, while in the plateau the unit cell is triclinic, space group $P \overline{1}$, and contains two independent $\mathrm{Fe}^{\mathrm{II}}$ sites with $\mathrm{HS}$ and LS spin states, respectively. This IP $=1$ HS-1LS defines the same checkerboard-like arrangement described for $\left[\mathrm{Fe}(\mathrm{bpe})_{2}(\mathrm{NCS})_{2}\right] \cdot 3$ (acetone) and $\left[\mathrm{Fe}\left(4,4^{\prime} \text {-bipy }\right)_{2}(\mathrm{NCX})_{2}\right] \cdot 4 \mathrm{CHCl}_{3}$. A re-entrant transition to the monoclinic $P 2_{1} / n$ space group is observed when the crystal goes to the LS state [72].

Bronisz et al. have reported the cationic 2D complex $\left[\mathrm{Fe}(\mathrm{bbtr})_{3}\right]\left(\mathrm{ClO}_{4}\right)_{2}(\mathrm{bbtr}=1,4$-bis $(1,2,3$ -triazol-1-yl)butane, see Appendix) which features an abrupt one step SCO with a hysteresis loop $8 \mathrm{~K}$ wide centered at $T_{\mathrm{c}}=105 \mathrm{~K}$. Furthermore, this compound displays upon cooling a crystallographic phase transition at $125 \mathrm{~K}$ that induces a change from trigonal (space group $P \overline{3}$ ), to triclinic (space group 
$P \overline{1})$. Interestingly, the isostructural $\mathrm{Zn}^{\mathrm{II}}$ derivative undergoes the same structural phase transition at $151 \mathrm{~K}$ with similar structural modifications as the $\mathrm{Fe}^{\mathrm{II}}$ compound. This circumstance was used to prepare solid solutions, $\left[\mathrm{Fe}_{x} \mathrm{Zn}_{1-x}(\mathrm{bbtr})_{3}\right]\left(\mathrm{ClO}_{4}\right)_{2}$, and separate both events, namely crystallographic phase transition and SCO. Indeed, an increase of $\mathrm{Zn}^{\mathrm{II}}$ content induces a proportional increase of the phase transition's temperature and a decrease of the SCO temperature without modifying its cooperative nature. This case is an example in which a crystallographic phase transition does not trigger directly the SCO but affords the necessary structural conditions [73].
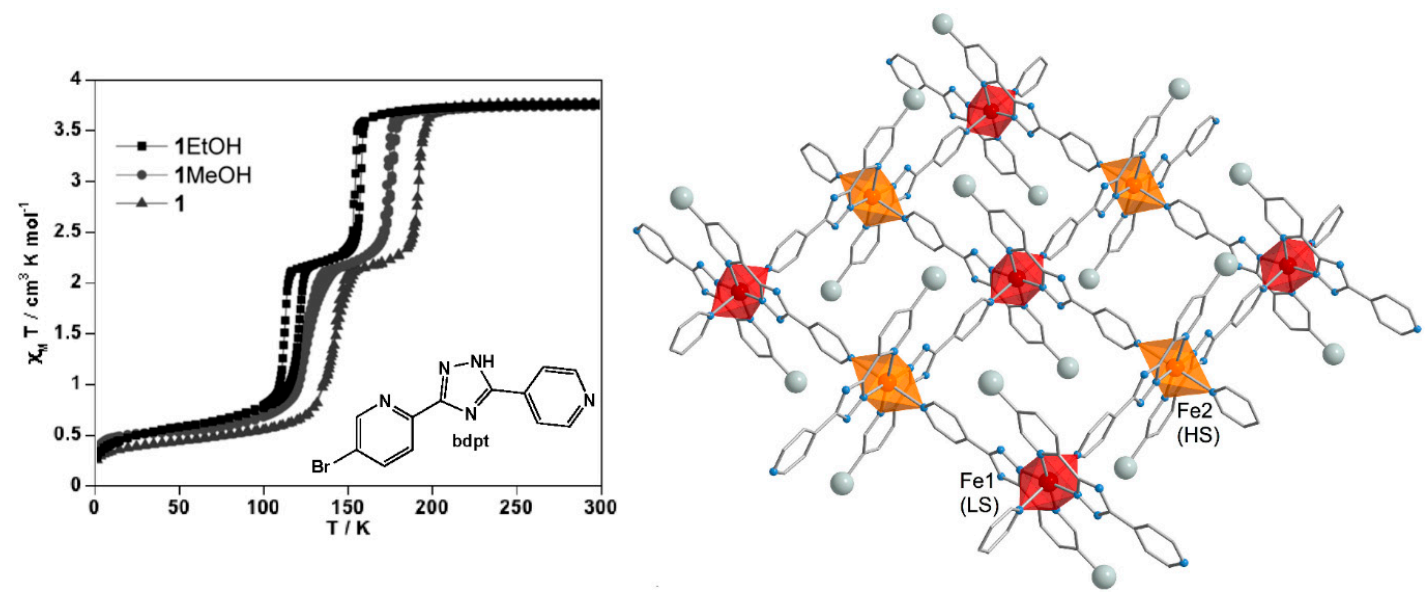

Figure 14. $\left[\mathrm{Fe}(\mathrm{bdpt})_{2}\right] \cdot \mathrm{nSolvent:}$ Spin crossover behavior (adapted with permission from Reference [72]) (left); and fragment of a layer displaying the checkerboard like 1HS-1LS order in the IP (right). Red and orange octahedrons correspond to LS and HS sites, respectively.

The three remaining examples belong to the family of heterobimetallic complexes derived from cyanometallate bridging building blocks. In these compounds the $\mathrm{Fe}^{\mathrm{II}}$ is axially coordinated by two monodentate pyridine-like ligands, while the equatorial positions are occupied by the cyanide moieties of four $\left[M(\mathrm{CN})_{2}\right]^{-}(M=\mathrm{Ag}, \mathrm{Au})$ or $\left[\mathrm{Pd}(\mathrm{CN})_{4}\right]^{2-}$ groups that act as bridges defining infinite layers. Two different $\mathrm{SCO}$ behaviors have been described for the complex $\left\{\mathrm{Fe}(3 \mathrm{Fpy})_{2}\left[\mathrm{Au}(\mathrm{CN})_{2}\right]\right\}$ (3Fpy $=3$-fluoropyridine). On one hand, the "form 1" reported by Real et al., displays a half SCO characterized by an asymmetric hysteresis loop $5 \mathrm{~K}$ wide centered at $T_{\mathrm{C}}=142.5 \mathrm{~K}$. At room temperature, the monoclinic (space group $P 2_{1} / c$ ) unit cell contains one independent $\mathrm{Fe}^{\mathrm{II}}$ site, which is in the HS state. At $120 \mathrm{~K}$, the triclinic (space group $P \overline{1}$ ) unit cell consists of two independent LS and HS Fe ${ }^{\mathrm{II}}$ sites displaying a checkerboard like arrangement (Figure 15). On the other hand, the "form 2", reported by Kitazawa et al., shows a complete two-step SCO with critical temperatures centered at $T_{\mathrm{c} 2}=147.9 \mathrm{~K}$ and $T_{\mathrm{c} 1}=108.4 \mathrm{~K}$ (hysteresis loop $\Delta T_{\mathrm{c} 1}=20.4 \mathrm{~K}$ ) (Figure 15). The crystal structures of the HS and the IP = 1HS-1LS reported by these authors for "form 2" are consistent with the structure reported for "form 1". The crystal structure of "form 2" solved at $80 \mathrm{~K}$ shows that in the LS state the crystal recovers the monoclinic (space group $P 2_{1} / c$ ) unit cell. Whatever the temperature, the packing is dominated by the occurrence strong aurophilic interactions between consecutive layers. Although the magnetic behavior of these samples suggests the existence of two polymorphs, it is difficult to justify them from a crystallographic viewpoint. Interestingly, application of low pressures $(0.16 \mathrm{GPa})$ induces complete two-step spin conversion in the "form 1" [74-76]. 
(a)

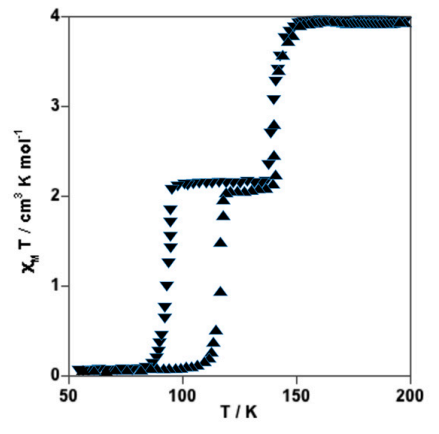

(b)

(c)

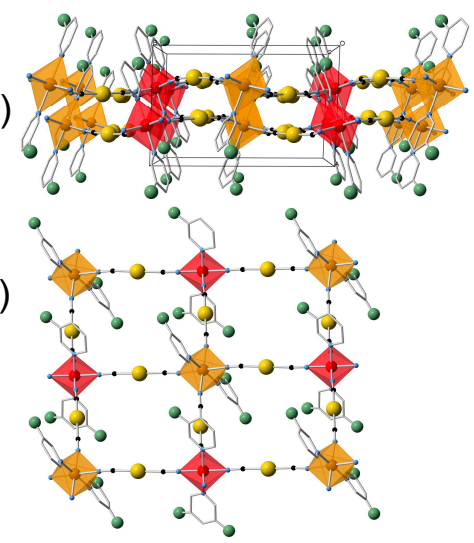

Figure 15. $\left\{\mathrm{Fe}(3 \mathrm{Fpy})_{2}\left[\mathrm{Au}(\mathrm{CN})_{2}\right]\right\}$ : (a) Spin crossover behavior (form 2); (b) perspective view of the packing of two consecutive layers along $c$ the $c$-axis in the IP $(123 \mathrm{~K})$; and (c) fragment of a layer along the $a$-axis in the IP (123 K). Red and orange octahedrons correspond to LS and HS Fe ${ }^{\mathrm{II}}$ sites, respectively, while green and yellow spheres represent $\mathrm{F}$ and $\mathrm{Au}$, respectively.

Real et al have reported the Hofmann-like 2D coordination polymer $\left\{\mathrm{Fe}(3-\mathrm{Clpy})_{2}\left[\mathrm{Pd}(\mathrm{CN})_{4}\right]\right\}$ (3-Clpy $=3$-Chloropyridine). This compound undergoes a strong cooperative two-step SCO, each one involving $50 \%$ of $\mathrm{Fe}^{\mathrm{II}}$ centers, with critical temperatures centered at $T_{\mathrm{c} 1}=144.9 \mathrm{~K}$ and $T_{\mathrm{c} 2}=162.1 \mathrm{~K}$ characterized by a hysteresis loop $7 \mathrm{~K}$ and $5 \mathrm{~K}$ wide, respectively. Above $160 \mathrm{~K}$, the HS state is characterized by an orthorhombic (space group Pnc2) unit cell, which contains one independent $\mathrm{Fe}^{\mathrm{II}}$ site, while in the IP ( $T=150 \mathrm{~K})$ the unit cell changes to orthorhombic (space group Pmna) where the 1HS-1LS state adopts the same orderly distribution described for most of the aforementioned two-dimensional coordination polymers (Figure 16). In the second step the crystal recovers the original $P n c 2$ space group characterized by one $\mathrm{Fe}^{\mathrm{II}} \mathrm{LS}$ site [77]. The same research group has described the complex $\left\{\mathrm{Fe}(\mathrm{DEAS})_{2}\left[\mathrm{Ag}(\mathrm{CN})_{2}\right]_{2}\right\}$ (DEAS $=4^{\prime}$-diethylaminostilbazole). This compound undergoes an incomplete $\mathrm{SCO}$ where $2 / 3$ of the $\mathrm{Fe}^{\mathrm{II}}$ centers remain in the $\mathrm{HS}$ state. The $\mathrm{SCO}$, characterized by a hysteresis loop $6 \mathrm{~K}$ wide centered at $T_{\mathrm{C}}=141 \mathrm{~K}$, is accompanied by a reversible crystallographic phase transition in which the volume of the unit-cell doubles in the low temperature phase. At $100 \mathrm{~K}$, there are six $\mathrm{Fe}^{\mathrm{II}}$ atoms per unit cell, two Fe1 and four Fe2. The average bond lengths, Fe1-N $\mathrm{N}^{\mathrm{av}}=1.969(4) \AA$ and $\mathrm{Fe} 2-\mathrm{N}^{\mathrm{av}}=2.176(4) \AA$, agree well with the $\mathrm{Fe}-\mathrm{N}$ bond distances typically found for the $\mathrm{Fe}{ }^{\mathrm{II}}$ ion in the LS and HS states, respectively. This singular fact perfectly correlates with the reported magnetic data at low temperature. In this IP $=2 \mathrm{HS}-1 \mathrm{LS}$ state the layers can be defined as generated by a sequence of $\cdots$ LS-HS-HS $\cdots$ columns (Figure 17) [78].

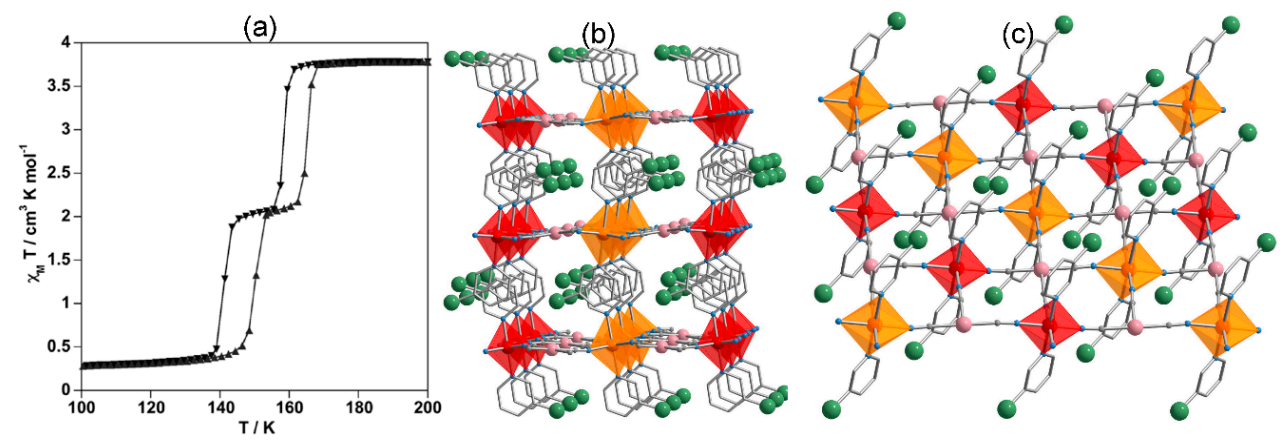

Figure 16. $\left\{\mathrm{Fe}(3-\mathrm{Clpy})_{2}\left[\mathrm{Pd}(\mathrm{CN})_{4}\right]\right\}$ : (a) Spin crossover behavior (b) perspective view of the packing of three consecutive layers seen along the $a$-axis in the IP $(150 \mathrm{~K})$; and (c) fragment of a layer in the IP state $(150 \mathrm{~K})$. Red and orange octahedrons correspond to LS and $\mathrm{HS} \mathrm{Fe}^{\mathrm{II}}$ sites, respectively, while green and pink spheres represent $\mathrm{Cl}$ and $\mathrm{Pd}$, respectively. 

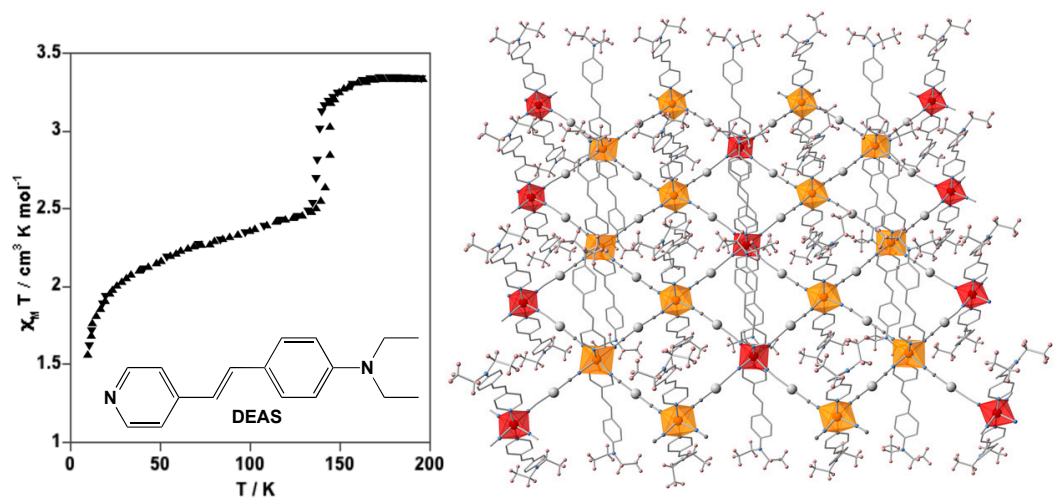

Figure 17. $\left\{\mathrm{Fe}(\mathrm{DEAS})_{2}\left[\mathrm{Ag}(\mathrm{CN})_{2}\right]_{2}\right\}$ : Spin crossover behavior (left) and perspective of a layer of in the IP $=2 \mathrm{HS}-1 \mathrm{LS}$ at $100 \mathrm{~K}$ (right). Red and orange octahedrons correspond to LS and HS Fe ${ }^{\mathrm{II}}$ sites, respectively.

\subsection{Three-Dimensional Coordination Polymers}

To the best of our knowledge, two examples of 3D coordination polymers displaying SCO and CSB have been reported so far. The compound $\left\{\mathrm{Fe}(5 \mathrm{Brpmd})_{2}\left[\mathrm{Ag}(\mathrm{CN})_{2}\right]_{2}\right\}$ (5Brpmd $=5$-bromo-pyrimidine), reported by Real et al., displays a strong cooperative half $\mathrm{SCO}$ centered at $T_{\mathrm{C}}=158 \mathrm{~K}$ characterized by a hysteresis loop $18 \mathrm{~K}$ wide. The $\mathrm{Fe}^{\mathrm{II}}$ centers are bridged by the bismonodentate ligand 5 Brpmd generating stacks of infinite $\cdots$ Fe- $(5 \mathrm{Brpmd})$-Fe $\cdots$ linear chains running parallel to the $a$-axis. The chains are interconnected through $\left[\mathrm{Ag}(\mathrm{CN})_{2}\right]^{-}$thus generating an intricate three-dimensional framework. The unit cell is monoclinic, $\mathrm{C} 2 / c$, in the $\mathrm{HS}$ state and displays one independent $\mathrm{Fe}^{\mathrm{II}}$ site with $\mathrm{Fe}-\mathrm{N}^{\mathrm{av}}=2.166(8) \AA(T=293 \mathrm{~K})$. However, at $120 \mathrm{~K}$ the monoclinic, $P 2_{1} / c$, unit cell contains, in agreement with the magnetic data, two independent $\mathrm{Fe}^{\mathrm{II}}$ sites: one is $\mathrm{HS}\left(\mathrm{Fe}-\mathrm{N}^{\mathrm{av}}=2.174(5) \AA\right)$ and the other is LS (Fe- $\left.\mathrm{N}^{\text {av }}=1.955(5) \AA\right)$. The HS and LS sites alternate along the infinite $\cdots$ Fe-(5Brpmd)-Fe $\cdots$ linear chains, which also define layers parallel to the ac plane (Figure 18) [79].
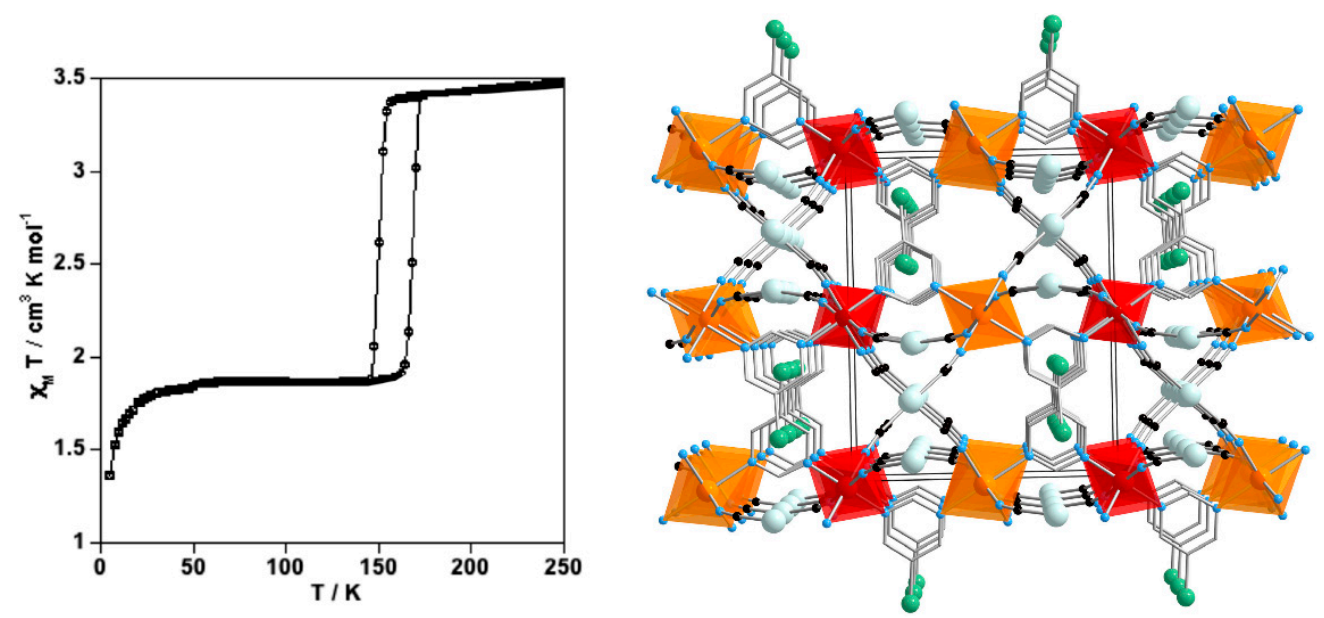

Figure 18. $\left\{\mathrm{Fe}(5 \mathrm{Brpmd})_{2}\left[\mathrm{Ag}(\mathrm{CN})_{2}\right]_{2}\right\}$ : Spin crossover behavior (adapted with permission from Reference [79]) (left); and projection of the unit cell on the $a b$ plane in the IP (120 K) (right). Red and orange octahedrons correspond to LS and $\mathrm{HS} \mathrm{Fe}^{\mathrm{II}}$ sites, respectively, while green and light-blue spheres represent $\mathrm{Br}$ and $\mathrm{Ag}$, respectively.

The complex $\left[\mathrm{Fe}(\mathrm{dpsme}) \mathrm{Pt}(\mathrm{CN})_{4}\right] \cdot 2 / 3 \mathrm{dpsme} \cdot \mathrm{xEtOH} \cdot \mathrm{yH}_{2} \mathrm{O}$ (dpsme $=4,4^{\prime}$-di(pyridylthio) methane), reported by Kepert et al., is a unique example of cooperative three-step SCO transition displaying CSB. In the interval $300-140 \mathrm{~K}, \mathrm{XM}_{\mathrm{M}} T=3.30 \mathrm{~cm}^{3} \cdot \mathrm{K} \cdot \mathrm{mol}^{-1}$ is consistent with the HS state of $\mathrm{Fe}^{\mathrm{II}}$ (state 1). In a first step, centered at $138 \mathrm{~K}$, the system reaches a plateau, $c a .10 \mathrm{~K}$ wide, with a 
$\chi_{\mathrm{M}} T$ value of $1.54 \mathrm{~cm}^{3} \cdot \mathrm{K} \cdot \mathrm{mol}^{-1}$, which is consistent with a $\mathrm{IP}_{1}=1 \mathrm{HS}-1 \mathrm{LS}$ (state 2 ). Then, a second drop of $\chi_{M} T$ in the temperature interval 130-125 K defines a new plateau with a $\chi_{M} T$ value equal to $1.01 \mathrm{~cm}^{3} \cdot \mathrm{K} \cdot \mathrm{mol}^{-1}$ (state 3 ). The $\chi_{M} T$ value of this second plateau is consistent with a IP $2=1 H S-2 \mathrm{LS}$. Below ca. $112 \mathrm{~K}$, the practically zero value of $\chi_{\mathrm{M}} T$ indicates a complete transformation to the LS state (state 4). In the heating mode the three-step behavior occurs ca. $20 \mathrm{~K}$ higher displaying an irregular hysteresis loop. In state 1 , the system is characterized by a monoclinic, $P 2 / a$, unit cell defined by one independent $\mathrm{Fe}^{\mathrm{II}}$ site, which is HS. In state 2 , the unit cell changes to triclinic, $P \overline{1}$, where two equally populated independent sites defining an ordered IP = 1LS:1HS characterized by alternating rows of LS and HS states as described for the related $\mathrm{Fe}(3-\mathrm{Clpy})_{2}\left[\mathrm{Pd}(\mathrm{CN})_{4}\right]$ (see Figure 16). The change from state 2 to state 3 involves doubling of the $P \overline{1}$ unit cell along the $a$-axis and concomitant generation of three crystallographically independent $\mathrm{Fe} \mathrm{II}^{\mathrm{II}}$ sites, i.e., two LS $\left(\mathrm{Fe}_{1}-\mathrm{N}^{\mathrm{av}}=1.944 \AA\right.$ and $\mathrm{Fe}_{2}-\mathrm{N}^{\mathrm{av}}=$ $1.991 \AA$ ), and one HS ( $\mathrm{Fe}_{3}-\mathrm{N}^{\mathrm{av}}=2.113 \AA$ ) with occupation factors $0.5,1$ and 0.5 , respectively. From a crystallographic point of view state 3 corresponds well with a $\mathrm{IP}_{2}=1 \mathrm{HS}: 3 \mathrm{LS}$, which is not consistent with the magnetic data. The authors suggest that a solid solution region with varying modulation along the $a$-axis may exist with conversion from 1HS-2LS to 1HS:3LS [80].

\section{Conclusions}

Here we have reviewed a variety of $\mathrm{Fe}^{\mathrm{II}}$ complexes that undergo reversible SCO and CSB, giving special emphasis to those systems displaying stepwise and ordering behavior. Complete two-step HS $\leftrightarrow$ LS conversion characterized by a 1HS-1LS symmetric distribution of both spin states in the IP can be considered the most common situation. A few examples of complete two-step SCO with asymmetric 2HS-1LS and 1HS-2LS distributions in the IP have also been described. In addition, incomplete SCO characterized by 1HS-1LS or 2HS-1LS stable low-temperature phases are also known. Thus far, only one example of three-step SCO involving successive generation of 1HS-1LS and 1HS-2LS IPs between the pure HS and LS phases has been described.

The IP states, easily identifiable as plateaus from the thermal dependence of the $\chi_{M}{ }^{T}$ product, represent macroscopic manifestations of precise microscopic distributions of HS and LS centers in the crystal, which can only be evidenced by X-ray diffraction analysis. The examples of order here highlighted represent an excellent platform to investigate the microscopic mechanisms, most likely based on cooperative and anticooperative elastic interactions, which could explain and predict the occurrence of different HS-LS patterns in the IP state. Understanding of these mechanisms is relevant for the control of the responsiveness of SCO materials and their possible integration in functional devices. We hope that this review will stimulate creative collaboration between the different involved areas of research, including coordination chemistry, materials science and solid-state physics.

Acknowledgments: This work was supported by the Spanish Ministerio de Economía y Competitividad (MINECO) and FEDER funds (CTQ2013-46275-P) and Generalitat Valenciana (PROMETEO/2012/049).

Conflicts of Interest: The authors declare no conflict of interest.

\section{Abbreviations}

The following abbreviations are used in this manuscript:

$\begin{array}{ll}\text { SCO } & \text { Spin crossover } \\ \text { CSB } & \text { Crystallographic symmetry breaking } \\ \text { HS } & \text { High-spin } \\ \text { LS } & \text { Low-spin } \\ \text { IP } & \text { Intermediate phase }\end{array}$




\section{Appendix}

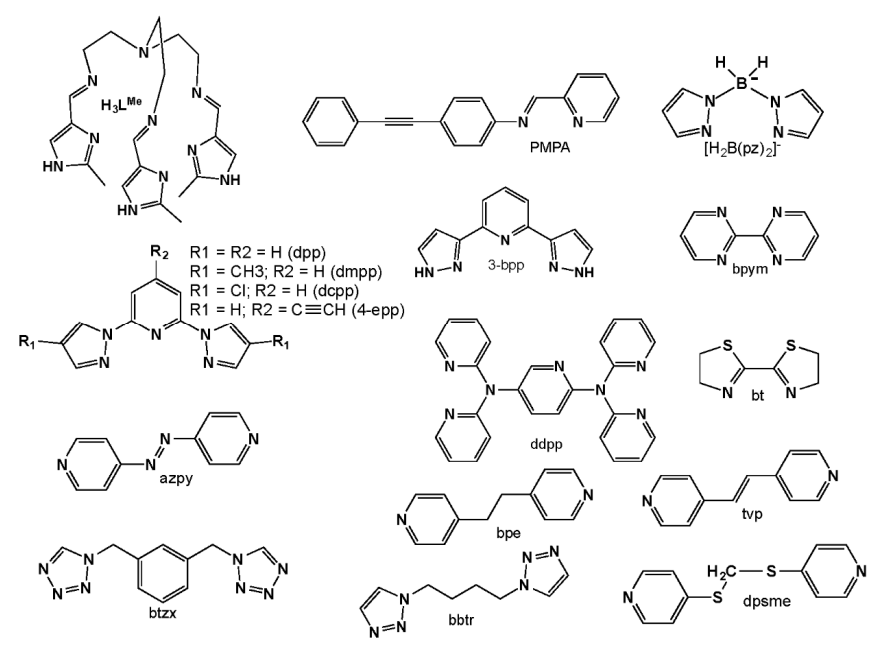

Figure A1. Ligands not described in the main text.

\section{References}

1. Olguin, J.; Brooker, S. Spin crossover active iron(II) complexes of selected pyrazole-pyridine/pyrazine ligands. Coord. Chem. Rev. 2011, 255, 203-240. [CrossRef]

2. Bousseksou, A.; Molnár, G.; Salmon, L.; Nicolazzi, W. Molecular spin crossover phenomenon: Recent achievements and prospects. Chem. Soc. Rev. 2011, 40, 3313-3335. [CrossRef] [PubMed]

3. Halcrow, M.A. Spin-crossover Materials: Properties and Applications; John Wiley \& Sons: Chichester, UK, 2013.

4. Muñoz, M.C.; Real, J.A. Thermo-, piezo-, photo- and chemo-switchable spin crossover iron(II)-metallocyanate based coordination polymers. Coord. Chem. Rev. 2011, 255, 2068-2093. [CrossRef]

5. Sasaki, N.; Kambara, T. Theory of the two-step spin conversion induced by the cooperative molecular distortions in spin-crossover compounds. Phys. Rev. B 1989, 40, 2442-2449. [CrossRef]

6. Bousseksou, A.; Nasser, J.; Linares, J.; Boukheddaden, K.; Varret, F. Ising-like model for the two-step spin-crossover. J. Phys. I 1992, 2, 1381-1403. [CrossRef]

7. Romstedt, H.; Spiering, H.; Gütlich, P. Modelling of two step high spin reversible arrow low spin transitions using the cluster variation method. J. Phys. Chem. Solids 1998, 59, 1353-1362. [CrossRef]

8. Real, J.A.; Bolvin, H.; Bousseksou, A.; Dworkin, A.; Kahn, O.; Varret, F.; Zarembowitch, J. Two-step spin crossover in the new dinuclear compound $\left[\mathrm{Fe}(\mathrm{bt})(\mathrm{NCS})_{2}\right]_{2}$ bpym, with bt =2,2'-Bi-2-thiazoline and bpym $=2,2$-Bipyrimidine: experimental investigation and theoretical approach. J. Am. Chem. Soc. 1992, 114, 4650-4658. [CrossRef]

9. Cirera, J.; Ruiz, E. Theoretical modeling of two-step spin-crossover transitions in $\mathrm{Fe}^{\mathrm{II}}$ dinuclear systems. J. Mater. Chem. C 2015, 3, 7954-7961. [CrossRef]

10. Niel, V.; Thompson, A.L.; Goeta, A.E.; Enachescu, C.; Hauser, A.; Galet, A.; Muñoz, M.C.; Real, J.A. Thermal- and photoinduced spin-state switching in an unprecedented three-dimensional bimetallic coordination polymer. Chem. Eur. J. 2005, 11, 2047-2060. [CrossRef] [PubMed]

11. Nihei, M.; Ui, M.; Yokota, M.; Han, L.; Maeda, A.; Kishida, H.; Okamoto, H.; Oshio, H. Two-step spin conversion in a cyanide-bridged ferrous square. Angew. Chem. Int. Ed. 2005, 44, 6484-6487. [CrossRef] [PubMed]

12. Shongwe, M.S.; Al-Rashdi, B.A.; Adams, H.; Morris, M.J.; Mikuriya, M.; Hearne, G.R. Thermally induced two-step, two-site incomplete ${ }^{6} \mathrm{~A}_{1} \leftrightarrow{ }^{2} \mathrm{~T}_{2}$ crossover in a mononuclear iron(III) phenolate-pyridyl Schiff-base complex: A rare crystallographic observation of the coexistence of pure $S=5 / 2$ and $1 / 2$ metal centers in the asymmetric unit. Inorg. Chem. 2007, 46, 9558-9568. [CrossRef] [PubMed] 
13. Klingele, J.; Kaase, D.; Klingele, M.H.; Lach, J.; Demeshko, S. Two-step spin crossover in the mononuclear iron(II) complex $\left[\mathrm{Fe}^{\mathrm{II}}(\mathrm{L})_{2}(\mathrm{NCS})_{2}\right]$ (L = 2,5-di-(2-pyridyl)-1,3,4-thiadiazole). Dalton Trans. 2010, 39, 1689-1691. [CrossRef] [PubMed]

14. Wei, R.-J.; Huo, Q.; Tao, J.; Huang, R.-B.; Zheng, L.-S. Spin-crossover Fe ${ }_{4}{ }_{4}$ squares: Two-step complete spin transition and reversible single-crystal-to-single-crystal transformation. Angew. Chem. Int. Ed. 2011, 50, 8940-8943. [CrossRef] [PubMed]

15. Bao, X.; Guo, P.-H.; Liu, W.; Tucek, J.; Zhang, W.-X.; Leng, J.-D.; Chen, X.-M.; Gural'skiy, I.; Salmon, L.; Bousseksou, A.; et al. Remarkably high-temperature spin transition exhibited by new 2D metal-organic frameworks. Chem. Sci. 2012, 3, 1629-1633. [CrossRef]

16. Klein, Y.M.; Sciortino, N.F.; Ragon, F.; Housecroft, C.E.; Kepert, C.J.; Neville, S.M. Spin crossover intermediate plateau stabilization in a flexible 2-D Hofmann-type coordination polymer. Chem. Commun. 2014, 50, 3838-3840. [CrossRef] [PubMed]

17. Piñeiro-López, L.; Seredyuk, M.; Muñoz, M.C.; Real, J.A. Two- and one-step cooperative spin transitions in Hofmann-like clathrates with enhanced loading capacity. Chem. Commun. 2014, 50, 1833-1835. [CrossRef] [PubMed]

18. Bhar, K.; Khan, S.; Sánchez-Costa, J.; Ribas, J.; Roubeau, O.; Mitra, P.; Ghosh, B.K. Crystallographic Evidence for Reversible Symmetry Breaking in a Spin-Crossover $\mathrm{d}^{7}$ Cobalt(II) Coordination Polymer. Angew. Chem. Int. Ed. 2012, 51, 2142-2145. [CrossRef] [PubMed]

19. Fitzpatrick, A.J.; Trzop, E.; Müller-Bunz, H.; Dîrtu, M.M.; Garcia, Y.; Collet, E.; Morgan, G.G. Electronic vs. structural ordering in a manganese(III) spin crossover complex. Chem. Commun. 2015, 51, 17540-17543. [CrossRef] [PubMed]

20. Griffin, M.; Shakespeare, S.; Shepherd, H.J.; Harding, C.J.; Létard, J.F.; Desplanches, C.; Goeta, A.E.; Howard, J.A.K.; Powell, A.K.; Mereacre, V.; et al. A Symmetry-Breaking Spin-State Transition in Iron(III). Angew. Chem. Int. Ed. 2011, 50, 896-900. [CrossRef] [PubMed]

21. Li, Z.-Y.; Dai, J.-W.; Shiota, Y.; Yoshizawa, K.; Kanegawa, S.; Sato, O. Multi-Step Spin Crossover Accompanied by Symmetry Breaking in an Fe $\mathrm{e}^{\mathrm{III}}$ Complex: Crystallographic Evidence and DFT Studies. Chem. Eur. J. 2013, 19, 12948-12952. [CrossRef] [PubMed]

22. Vieira, B.J.C.; Coutinho, J.T.; Santos, I.C.; Pereira, L.C.J.; Waerenborgh, J.C.; da Gama, V. [Fe(nsal 2 trien)]SCN, a new two-step iron(III) spin srossover compound, with symmetry breaking spin-state transition and an intermediate ordered state. Inorg. Chem. 2013, 52, 3845-3850. [CrossRef] [PubMed]

23. Murnaghan, K.D.; Carbonera, C.; Toupet, L.; Griffin, M.; Dîrtu, M.M.; Desplanches, C.; Garcia, Y.; Collet, E.; Létard, J.F.; Morgan, G.G. Spin-state ordering on one sub-lattice of a mononuclear iron(III) spin crossover complex exhibiting LIESST and TIESST. Chem. Eur. J. 2014, 20, 5613-5618. [CrossRef] [PubMed]

24. Harding, D.J.; Phonsri, W.; Harding, P.; Murray, K.S.; Moubaraki, B.; Jameson, G.N.L. Abrupt two-step and symmetry breaking spin crossover in an iron(III) complex: An exceptionally wide [LS-HS] plateau. Dalton Trans. 2015, 44, 15079-15082. [CrossRef] [PubMed]

25. Shatruk, M.; Phana, H.; Chrisostomoa, B.A.; Suleimenov, A. Symmetry-breaking structural phase transitions in spin crossover complexes. Coord. Chem. Rev. 2015, 289-290, 62-73. [CrossRef]

26. Gütlich, P.; Hauser, A.; Spiering, H. Thermal and optical switching of iron(ii) complexes. Angew. Chem. Int. Ed. 1994, 33, 2024-2054. [CrossRef]

27. Katz, B.A.; Strouse, C.E. Molecular-transformations in the solid-state. Crystallographic resolution of the spin isomers of tris(2-picolylamine)iron(II) dichloride and the structural relationship between the methanol and ethanol solvates. J. Am. Chem. Soc. 1979, 101, 6214-6221. [CrossRef]

28. Mikami, M.; Konno, M.; Saito, Y. Structures of high-spin (298, $150 \mathrm{~K})$ and low-spin (90 K) states and the spin phase-transition mechanism of a spin crossover complex; tris( $\alpha$-picolylamine)iron(II) chloride-ethanol. Acta Cryst. 1980, B36, 275-287. [CrossRef]

29. Köppen, H.; Müller, E.W.; Köhler, C.P.; Spiering, H.; Meissner, E.; Gütlich, P. Unusual spin-transition anomaly in the crossover system [Fe(2-pic) $\left.{ }_{3}\right]_{C}$. EtOH. Chem. Phys. Lett. 1982, 91, 348-352. [CrossRef]

30. Meissner, E.; Köppen, H.; Spiering, H.; Gütlich, P. The effect of low-pressure on a high-spin low-spin transition. Chem. Phys. Lett. 1983, 95, 163-166. [CrossRef]

31. Kaji, K.; Sorai, M. Heat-capacity and dual spin-transitions in the crossover system $\left[\mathrm{Fe}(2-\mathrm{pic})_{3}\right] \mathrm{Cl}_{2} \cdot \mathrm{EtOH}$ Thermochim. Acta 1985, 88, 185-190. [CrossRef] 
32. Spiering, H.; Kohlhaas, T.; Romstedt, H.; Hauser, A.; Bruns-Yilmaz, C.; Gütlich, P. Correlations of the distribution of spin states in spin crossover compounds. Coord. Chem. Rev. 1999, 190-192, 629-647. [CrossRef]

33. Chernyshov, D.; Hostettler, M.; Törnroos, K.W.; Bürgi, H.B. Ordering phenomena and phase transitions in a spin-crossover compound-uncovering the nature of the intermediate phase of $\left[\mathrm{Fe}(2-\mathrm{pic})_{3}\right] \mathrm{Cl}_{2} \cdot \mathrm{EtOH}$. Angew. Chem. Int. Ed. 2003, 42, 3825-3830. [CrossRef] [PubMed]

34. Money, V.A.; Carbonera, C.; Elhaïk, J.; Halcrow, M.A.; Howard, J.A.K.; Létard, J.F. Interplay between kinetically slow thermal spin-crossover and metastable high-spin state relaxation in an iron(II) complex with similar $\mathrm{T}_{1 / 2}$ and T(LIESST). Chem. Eur. J. 2007, 13, 5503-5514. [CrossRef] [PubMed]

35. Luan, J.; Zhou, J.; Liu, Z.; Zhu, B.; Wang, H.; Bao, X.; Liu, W.; Tong, M.L.; Peng, G.; Peng, H.; et al. Polymorphism-dependent spin-crossover: Hysteretic two-step spin transition with an ordered [HS-HS-LS] intermediate phase. Inorg. Chem. 2015, 54, 5145-5147. [CrossRef] [PubMed]

36. Nihei, M.; Tahira, H.; Takahashi, N.; Otake, Y.; Yamamura, Y.; Saito, K.; Oshio, H. Multiple bistability and tristability with dual spin-state conversions in $\left[\mathrm{Fe}(\mathrm{dpp})_{2}\right]\left[\mathrm{Ni}(\mathrm{mnt})_{2}\right]_{2} \cdot \mathrm{MeNO}_{2}$. J. Am. Chem. Soc. 2010, 132, 3553-3560. [CrossRef] [PubMed]

37. Boinnard, D.; Bousseksou, A.; Dworkin, A.; Savariault, J.M.; Varret, F.; Tuchagues, J.P. Two-step spin conversion of $\left[\mathrm{Fe}^{\mathrm{II}}\left(5-\mathrm{NO}_{2}\right.\right.$-sal-N $\left.\left.(1,4,7,10)\right)\right]: 292,153$, and $103 \mathrm{~K}$. X-ray crystal and molecular-structure and infrared, magnetic, mossbauer, calorimetric, and theoretical-studies. Inorg. Chem. 1994, 33, 271-281. [CrossRef]

38. Reger, D.L.; Little, C.A.; Young, V.G., Jr.; Pink, M. Variable-temperature X-ray structural investigation of $\left\{\mathrm{Fe}\left[\mathrm{HC}\left(3,5-\mathrm{Me}_{2} \mathrm{pz}\right)_{3}\right]_{2}\right\}\left(\mathrm{BF}_{4}\right)_{2}(\mathrm{pz}=$ pyrazolyl ring): Observation of a thermally induced spin state change from all high spin to an equal high spin-low spin mixture, concomitant with the onset of nonmerohedral twinning. Inorg. Chem. 2001, 40, 2870-2874. [PubMed]

39. Yamada, M.; Hagiwara, H.; Torigoe, H.; Matsumoto, N.; Kojima, M.; Dahan, F.; Tuchagues, J.P.; Re, N.; Iijima, $\mathrm{S}$. A variety of spin-crossover behaviors depending on the counter anion: Two-dimensional complexes constructed by $\mathrm{NH} \cdots \mathrm{Cl}^{-}$hydrogen bonds, $\left[\left(\mathrm{Fe}^{\mathrm{II}} \mathrm{H}_{3} \mathrm{LMe}\right)\right] \mathrm{Cl} \cdot \mathrm{X}\left(\mathrm{X}=\mathrm{PF}_{6}{ }^{-}, \mathrm{AsF}_{6}{ }^{-}, \mathrm{SbF}_{6}{ }^{-}, \mathrm{CF}_{3} \mathrm{SO}_{3}{ }^{-} ; \mathrm{H}_{3} \mathrm{LMe}^{-}\right.$ $=\operatorname{tris}[2-\{[(2-m e t h y l i m i d a z o l-4-y l) m e t h y l i d e n e] a m i n o\} e t h y l] a m i n e)$. Chem. Eur. J. 2006, 12, 4536-4549. [PubMed]

40. Sato, T.; Nishi, K.; Iijima, S.; Kojima, M.; Matsumoto, N. One-step and two-step spin-crossover iron(II) complexes of ((2-methylimidazol-4-yl)methylidene)histamine. Inorg. Chem. 2009, 48, 7211-7229. [CrossRef] [PubMed]

41. Bréfuel, N.; Collet, E.; Watanabe, H.; Kojima, M.; Matsumoto, N.; Toupet, L.; Tanaka, K.; Tuchagues, J.P. Nanoscale self-hosting of molecular spin-states in the intermediate phase of a spin-crossover material. Chem. Eur. J. 2010, 16, 14060-14068. [CrossRef] [PubMed]

42. Bréfuel, N.; Watanabe, H.; Toupet, L.; Come, J.; Matsumoto, N.; Collet, E.; Tanaka, K.; Tuchagues, J.P. Concerted spin crossover and symmetry breaking yield three thermally and one light-induced crystallographic phases of a molecular material. Angew. Chem. Int. Ed. 2009, 48, 9304-9307. [CrossRef] [PubMed]

43. Bonnet, S.; Siegler, M.A.; Sánchez-Costa, J.; Molnár, G.; Bousseksou, A.; Spek, A.L.; Gamez, P.; Reedijk, J. A two-step spin crossover mononuclear iron(II) complex with a [HS-LS-LS] intermediate phase. Chem. Commun. 2008, 5619-5621. [CrossRef] [PubMed]

44. Létard, J.F.; Guionneau, P.; Codjovi, E.; Lavastre, O.; Bravic, G.; Chasseau, D.; Kahn, O. Wide thermal hysteresis for the mononuclear spin-crossover compound cis-bis(thiocyanato)bis[N-(2'-pyridylmethylene)-4(phenylethynyl)anilino]iron(II). J. Am. Chem. Soc. 1997, 119, 10861-10862. [CrossRef]

45. Thompson, A.L.; Goeta, A.E.; Real, J.A.; Galet, A.; Muñoz, M.C. Thermal and light induced polymorphism in iron(II) spin crossover compounds. Chem. Commun. 2004, 1390-1391. [CrossRef] [PubMed]

46. Carbonera, C.; Saánchez-Costa, J.; A. Money, V.; Elhaïk, J.; Howard, J.A. K.; Halcrow, M.A.; Létard, J.F. Photomagnetic properties of iron(II) spin crossover complexes of 2,6-dipyrazolylpyridine and 2,6-dipyrazolylpyrazine ligands. Dalton Trans. 2006, 3058-3066. [CrossRef] [PubMed]

47. Pritchard, R.; Kilner, C.A.; Halcrow, M.A. Iron(II) complexes with a terpyridine embrace packing motif show remarkably consistent cooperative spin-transitions. Chem. Commun. 2007, 577-579. [CrossRef] [PubMed]

48. Salitros, I.; Fuhr, O.; Eichhöfer, A.; Kruk, R.; Pavlik, J.; Dlhán, L.; Boca, R.; Ruben, M. The interplay of iron(II) spin transition and polymorphism. Dalton Trans. 2012, 41, 5163-5171. [CrossRef] [PubMed] 
49. Sugiyarto, K.H.; McHale, W.A.; Craig, D.C.; Rae, A.D.; Scudder, M.L.; Goodwin, H.A. Spin transition centres linked by the nitroprusside ion. The cooperative transition in bis(2,6-bis(pyrazol-3-yl)-pyridine)iron(II) nitroprusside. Dalton Trans. 2003, 2443-2448. [CrossRef]

50. Bréfuel, N.; Imatomi, S.; Torigoe, H.; Hagiwara, H.; Shova, S.; Meunier, J.F.; Bonhommeau, S.; Tuchagues, J.P.; Matsumoto, N. Structural-electronic correlation in the first-order phase transition of $\left[\mathrm{FeH}_{2} \mathrm{~L}^{2-M e}\right]\left(\mathrm{ClO}_{4}\right)_{2}$ $\left(\mathrm{H}_{2} \mathrm{~L}^{2-M e}=\right.$ bis[((2-methylimidazol-4-yl)methylidene)-3-aminopropyl]ethylenediamine). Inorg. Chem. 2006, 45, 8126-8135. [CrossRef] [PubMed]

51. Tafili-Kryeziu, M.; Weil, M.; Muranaka, T.; Bousseksou, A.; Hasegawa, M.; Junc, A.; Linert, W. Effect of the counter-anion on the spin-transition properties of a family of $\mathrm{Fe}(\mathrm{II})$ tetrazole complexes, $\left[\mathrm{Fe}(\mathrm{i} 4 \mathrm{tz})_{6}\right] \mathrm{X}_{2}(\mathrm{X}=$ $\mathrm{ClO}_{4}{ }^{-}, \mathrm{PF}_{6}{ }^{-}, \mathrm{SbF}_{6}{ }^{-}, \mathrm{BF}_{4}{ }^{-}$). Dalton Trans. 2013, 42, 15796-15804. [CrossRef] [PubMed]

52. Real, J.A.; Zarembowitch, J.; Kahn, O.; Solans, X. Magnetic interaction and spin transition in iron(II) dinuclear compounds. Crystal-structure of ( $\mu-2,2^{\prime}$-bipyrimidine)bis[(2,2'-bipyrimidine) bis(thiocyanato)iron(II)]. Inorg. Chem. 1987, 26, 2939-2943. [CrossRef]

53. Real, J.A.; Castro, I.; Bousseksou, A.; Verdaguer, M.; Burriel, R.; Castro, M.; Linares, J.; Varret, F. Spin crossover in the 2,2'-bipyrimidine-(bpym-) bridged iron(II) complexes $\left[\mathrm{Fe}(\mathrm{L})(\mathrm{NCX})_{2}\right]_{2}$ (bpym) $\left(\mathrm{L}=2,2^{\prime}\right.$-bithiazoline (bt) and bpym; $\mathrm{X}=\mathrm{S}$, Se). X-ray absorption spectroscopy, magnetic susceptibility, calorimetric, and Mossbauer spectroscopy studies. Inorg. Chem. 1997, 36, 455-464. [CrossRef]

54. Létard, J.F.; Real, J.A.; Moliner, N.; Gaspar, A.B.; Capes, L.; Cador, O.; Kahn, O. Light induced excited pair spin state in an iron(II) binuclear spin-crossover compound. J. Am. Chem. Soc. 1999, 121, 10630-10631. [CrossRef]

55. Real, J.A.; Gaspar, A.B.; Muñoz, M.C.; Gütlich, P.; Ksenofontov, V.; Spiering, H. Bipyrimidine-bridged dinuclear iron(II) spin crossover compounds. Top. Curr. Chem. 2004, 233, 167-193.

56. Bousseksou, A.; Molnár, G.; Real, J.A.; Tanaka, K. Spin crossover and photomagnetism in dinuclear iron(II) compounds. Coord. Chem. Rev. 2007, 251, 1822-1833. [CrossRef]

57. Moussa, N.O.; Molnár, G.; Bonhommeau, S.; Zwick, A.; Mouri, S.; Tanaka, K.; Real, J.A.; Bousseksou, A. Selective photoswitching of the binuclear spin crossover compound $\left\{\left[\mathrm{Fe}(\mathrm{bt})(\mathrm{NCS})_{2}\right]_{2}(\mathrm{bpm})\right\}$ into two distinct macroscopic phases. Phys. Rev. Lett. 2005, 94. [CrossRef] [PubMed]

58. Gaspar, A.B.; Ksenofontov, V.; Reiman, S.; Gütlich, P.; Thompson, A.L.; Goeta, A.E.; Muñoz, M.C.; Real, J.A. Mossbauer investigation of the photoexcited spin states and crystal structure analysis of the spin-crossover dinuclear complex $\left[\left\{\mathrm{Fe}(\mathrm{bt})(\mathrm{NCS})_{2}\right)_{2} \mathrm{bpym}\right]\left(\mathrm{bt}=2,2^{\prime}\right.$-bithiazoline, bpym $=2,2^{\prime}$-bipyrimidine). Chem. Eur. J. 2006, 12, 9289-9298. [CrossRef] [PubMed]

59. Trzop, E.; Buron-Le Cointe, M.; Cailleau, H.; Toupet, L.; Molnár, G.; Bousseksou, A.; Gaspar, A.B.; Real, J.A.; Collet, E. Structural investigation of the photoinduced spin conversion in the dinuclear compound $\left\{\left[\mathrm{Fe}(\mathrm{bt})(\mathrm{NCS})_{2}\right]_{2}(\mathrm{bpym})\right\}$ : Toward controlled multi-stepped molecular switches. J. Appl. Cryst. 2007, 40, 158-164. [CrossRef]

60. Gaspar, A.B.; Muñoz, M.C.; Real, J.A. Dinuclear iron(II) spin crossover compounds: Singular molecular materials for electronics. J. Mater. Chem. 2006, 16, 2522-2533. [CrossRef]

61. Nakano, K.; Kawata, S.; Yoneda, K.; Fuyuhiro, A.; Yagi, T.; Nasu, S.; Morimoto, S.; Kaizaki, S. Direct two-step spin-crossover through [HS-HS] . . [LS-LS] at the plateau in dinuclear diiron(II) complex $\left[\left\{\mathrm{Fe}\left(\mathrm{NCBH}_{3}\right)(4 \mathrm{phpy})\right\}_{2}(\mu-\mathrm{bpypz})_{2}\right]$. Chem. Commun. 2004, 2892-2893. [CrossRef] [PubMed]

62. Klingele, M.H.; Moubaraki, B.; Cashion, J.D.; Murray, K.S.; Brooker, S. The first X-ray crystal structure determination of a dinuclear complex trapped in the [low spin-high spin] state: $\left[\mathrm{Fe}_{2}{ }_{2}(\mathrm{PMAT})_{2}\right]\left(\mathrm{BF}_{4}\right) \cdot \mathrm{DMF}$. Chem. Commun. 2005, 987-989. [CrossRef] [PubMed]

63. Amoore, J.J.M.; Kepert, C.J.; Cashion, J.D.; Moubaraki, B.; Neville, S.M.; Murray, K.S. Structural and magnetic resolution of a two-step full spin-crossover transition in a dinuclear iron(II) pyridyl-bridged compound. Chem. Eur. J. 2006, 12, 8220-8227. [CrossRef] [PubMed]

64. Fedaoui, D.; Bouhadja, Y.; Kaiba, A.; Guionneau, P.; Létard, J.F.; Rosa, P. Complexation of 2,6-bis(3-pyrazolyl)pyridine-bis(thiocyanato)iron(II) with a bridging 4,4'-bipyridine: A new example of a dinuclear spin crossover complex. Eur. J. Inorg. Chem. 2008, 2008, 1022-1026. [CrossRef]

65. Kaiba, A.; Shepherd, H.J.; Fedaoui, D.; Rosa, P.; Goeta, A.E.; Rebbani, N.; Létard, J.F.; Guionneau, P. Crystallographic elucidation of purely structural, thermal and light-induced spin transitions in an iron(II) binuclear complex. Dalton Trans. 2010, 39, 2910-2918. [CrossRef] [PubMed] 
66. Bauer, W.; Pfaffeneder, T.; Achterhold, K.; Weber, B. Complete two-step spin-transition in a 1D chain iron(II) complex with a 110-K wide intermediate plateau. Eur. J. Inorg. Chem. 2011, 2011, 3183-3192. [CrossRef]

67. Quesada, M.; Prins, F.; Bill, E.; Kooijman, H.; Gamez, P.; Roubeau, O.; Spek, A.L.; Haasnoot, J.G.; Reedijk, J. Counterion effect on the spin-transition properties of the cation $\left[\mathrm{Fe}(\mathrm{btzx})_{3}\right]^{2+}(\mathrm{btzx}=\mu$-xylylenebis(tetrazole $\left.)\right)$. Chem. Eur. J. 2008, 14, 8486-8499. [CrossRef] [PubMed]

68. Patrick, B.O.; Reiff, W.M.; Sanchez, V.; Storr, A.; Thompson, R.C. Poly(2,2-bipyridine)tetrakis (imidazolato)diiron(II): Structural and spin-state phase transitions and low-temperature magnetic ordering in a unique 2-dimensional material. Inorg. Chem. 2004, 43, 2330-2339. [CrossRef] [PubMed]

69. Halder, G.J.; Chapman, K.W.; Neville, S.M.; Moubaraki, B.; Murray, K.S.; Létard, J.F.; Kepert, C.J. Elucidating the mechanism of a two-step spin transition in a nanoporous metal-organic framework. J. Am. Chem. Soc. 2008, 130, 17552-17562. [CrossRef] [PubMed]

70. Romero-Morcillo, T.; de la Pinta, N.; Callejo, L.M.; Piñeiro-López, L.; Muñoz, M.C.; Madariaga, G.; Ferrer, S.; Breczewski, T.; Cortés, R.; Real, J.A. Nanoporosity, inclusion chemistry, and spin crossover in orthogonally interlocked two-dimensional metal-organic frameworks. Chem. Eur. J. 2015, 21, 12112-12120. [CrossRef] [PubMed]

71. Adams, C.J.; Muñoz, M.C.; Waddington, R.E.; Real, J.A. Cooperative spin transition in the two-dimensional coordination polymer $\left[\mathrm{Fe}\left(4,4^{\prime} \text {-bipyridine }\right)_{2}(\mathrm{NCX})_{2}\right) \cdot 4 \mathrm{CHCl}_{3}(\mathrm{X}=\mathrm{S}$, Se). Inorg. Chem. 2011, 50, 10633-10642. [CrossRef] [PubMed]

72. Lin, J.-B.; Xue, W.; Wang, B.-Y.; Tao, J.; Zhang, W.-X.; Zhang, J.-P.; Chen, X.-M. Chemical/physical pressure tunable spin-transition temperature and hysteresis in a two-step spin crossover porous coordination framework. Inorg. Chem. 2012, 51, 9423-9430. [CrossRef] [PubMed]

73. Kusz, J.; Bronisz, R.; Zubko, M.; Bednarek, G. On the role of intermolecular interactions on structural and spin-crossover properties of 2D coordination networks [Fe(bbtr) $\left.{ }_{3}\right]_{2}$ (bbtr = 1,4-bis(1,2,3-triazol-1-yl)butane; $\mathrm{A}=\mathrm{ClO}_{4}{ }^{-}, \mathrm{BF}_{4}^{-}$). Chem. Eur. J. 2011, 17, 6807-6820. [CrossRef] [PubMed]

74. Agustí, G.; Muñoz, M.C.; Gaspar, A.B.; Real, J.A. Spin-crossover behavior in cyanide-bridged Iron(II)-Gold(I) bimetallic 2D Hofmann-like metal-organic frameworks. Inorg. Chem. 2008, 47, 2552-2561. [CrossRef] [PubMed]

75. Kosone, T.; Kachi-Terajima, C.; Kanadani, C.; Saito, T.; Kitazawa, T. A two-step and hysteretic spin-crossover transition in new cyano-bridged hetero-metal $\mathrm{Fe}^{\mathrm{II}} \mathrm{Au}^{\mathrm{I}}$ 2-dimensional assemblage. Chem. Lett. 2008, 37, 422-423. [CrossRef]

76. Kosone, T.; Kanadani, C.; Saito, T.; Kitazawa, T. Synthesis, crystal structures, magnetic properties and fluorescent emissions of two-dimensional bimetallic coordination frameworks Fe ${ }^{\mathrm{II}}$ (3-fluoropyridine) 2 $\left[\mathrm{Au}^{\mathrm{I}}(\mathrm{CN})_{2}\right]_{2}$ and $\mathrm{Mn}^{\mathrm{II}}$ (3-fluoropyridine $)_{2}\left[\mathrm{Au}^{\mathrm{I}}(\mathrm{CN})_{2}\right]_{2}$. Polyhedron 2009, 28, 1930-1934. [CrossRef]

77. Martínez, V.; Gaspar, A.B.; Muñoz, M.C.; Bukin, G.V.; Levchenko, G.; Real, J.A. Synthesis and characterisation of a new series of bistable iron(II) spin-crossover 2D metal-organic frameworks. Chem. Eur. J. 2009, 15, 10960-10971. [CrossRef] [PubMed]

78. Agustí, G.; Gaspar, A.B.; Muñoz, M.C.; Lacroix, P.G.; Real, J.A. Spin crossover and paramagnetic behaviour in two-dimensional iron(II) coordination polymers with stilbazole push-pull ligands. Aust. J. Chem. 2009, 62, 1155-1165. [CrossRef]

79. Agustí, G.; Gaspar, A.B.; Muñoz, M.C.; Real, J.A. Thermal- and pressure-induced cooperative spin transition in the $2 \mathrm{D}$ and $3 \mathrm{D}$ coordination polymers $\left.\left.\left\{\mathrm{Fe}(5-\mathrm{Br}-\mathrm{pmd})_{\mathrm{z}}\right] \mathrm{M}(\mathrm{CN})_{\mathrm{x}}\right]_{y}\right\}\left(\mathrm{M}=\mathrm{Ag}^{\mathrm{I}}, \mathrm{Au}^{\mathrm{I}}, \mathrm{Ni}^{\mathrm{II}}, \mathrm{Pd}^{\mathrm{II}}, \mathrm{Pt}^{\mathrm{II}}\right)$. Inorg. Chem. 2007, 46, 9646-9654. [CrossRef] [PubMed]

80. Sciortino, N.F.; Scherl-Gruenwald, K.R.; Chastanet, G.; Halder, G.J.; Chapman, K.W.; Létard, J.F.; Kepert, C.J. Hysteretic three-step spin crossover in a thermo- and photochromic 3D pillared Hofmann-type metal-organic framework. Angew. Chem. Int. Ed. 2012, 51, 10154-10158. [CrossRef] [PubMed]

(C) 2016 by the authors; licensee MDPI, Basel, Switzerland. This article is an open access article distributed under the terms and conditions of the Creative Commons by Attribution (CC-BY) license (http://creativecommons.org/licenses/by/4.0/). 